\title{
A new lineage of Cretaceous jewel wasps (Chalcidoidea: Diversinitidae)
}

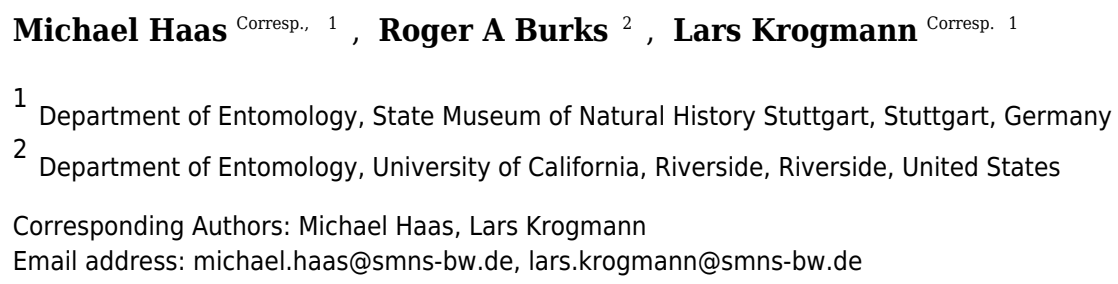

Jewel wasps (Hymenoptera: Chalcidoidea) are extremely species-rich today, but have a sparse fossil record from the Cretaceous, the period of their early diversification. Three genera and three species, Diversinitus attenboroughi gen. \& sp. n., Burminata caputaeria gen. \& sp. n. and Glabiala barbata gen. \& sp. n. are described in the family Diversinitidae fam. n., from Lower Cretaceous Burmese amber. Placement in Chalcidoidea is supported by the presence of multiporous plate sensilla on the antennal flagellum and a laterally exposed prepectus. The new taxa can be excluded from all extant family level chalcidoid lineages by the presence of multiporous plate sensilla on the first flagellomere in both sexes and lack of any synapomorphies. Accordingly, a new family is proposed for the fossils and its probable phylogenetic position within Chalcidoidea is discussed. Morphological cladistic analyses of the new fossils within the Heraty et al. (2013) dataset did not resolve the phylogenetic placement of Diversinitidae, but indicated its monophyly. Phylogenetically relevant morphological characters of the new fossils are discussed with reference to Cretaceous and extant chalcidoid taxa. Along with mymarid fossils and a few species of uncertain phylogenetic placement, the newly described members of Diversinitidae are among the earliest known chalcidoids and advance our knowledge of their Cretaceous diversity. 


\section{A new lineage of Cretaceous jewel wasps (Chalcidoidea: 2 Diversinitidae)}

3 Michael Haas ${ }^{1}$, Roger A. Burks ${ }^{2}$, Lars Krogmann ${ }^{1}$

$4{ }^{1}$ Department of Entomology, State Museum of Natural History Stuttgart, 70191 Stuttgart, Germany

$5 \quad{ }^{2}$ Department of Entomology, University of California, Riverside, CA, 92521, USA

6

7 Corresponding Authors:

8 Michael Haas $^{1}$, Lars Krogmann ${ }^{1}$

9 Rosenstein 1, 70191 Stuttgart, Germany

10 Email addresses: michael.haas@smns-bw.de, lars.krogmann@smns-bw.de 
11

12

13

14

15

16

17

18

19

20

21

22

23

24

25

26

27

28

\section{Abstract}

Jewel wasps (Hymenoptera: Chalcidoidea) are extremely species-rich today, but have a sparse fossil record from the Cretaceous, the period of their early diversification. Three genera and three species, Diversinitus attenboroughi gen. \& sp. n., Burminata caputaeria gen. \& sp. n. and Glabiala barbata gen. \& sp. n. are described in the family Diversinitidae fam. n., from Lower Cretaceous Burmese amber. Placement in Chalcidoidea is supported by the presence of multiporous plate sensilla on the antennal flagellum and a laterally exposed prepectus. The new taxa can be excluded from all extant family level chalcidoid lineages by the presence of multiporous plate sensilla on the first flagellomere in both sexes and lack of any synapomorphies. Accordingly, a new family is proposed for the fossils and its probable phylogenetic position within Chalcidoidea is discussed. Morphological cladistic analyses of the new fossils within the Heraty et al. (2013) dataset did not resolve the phylogenetic placement of Diversinitidae, but indicated its monophyly. Phylogenetically relevant morphological characters of the new fossils are discussed with reference to Cretaceous and extant chalcidoid taxa. Along with mymarid fossils and a few species of uncertain phylogenetic placement, the newly described members of Diversinitidae are among the earliest known chalcidoids and advance our knowledge of their Cretaceous diversity.

\section{Introduction}

Jewel wasps (Hymenoptera: Chalcidoidea) are estimated to constitute one of the most speciesrich insect lineages. Estimated numbers range from 100,000 to 500,000 species, which may comprise $10 \%$ of insect diversity, though only about 22,000 species have been described to date (Noyes, 1978, 2000, 2017; Heraty \& Gates, 2001). Their evolutionary success is mirrored by and likely results from their varied biological life styles. Jewel wasps develop mainly as parasitoids of 13 different insect orders, as well as some nematodes, pseudoscorpions and arachnids, and thus are essential beneficial regulators, while some species are phytophages or even obligate pollinators of figs (Ficus) (Gibson, Heraty \& Woolley, 1999; Weiblen, 2002; Heraty, 2009). Despite recent progress (Munro et al., 2011; Heraty et al., 2013; Peters et al., 2018), the relationships among most chalcidoid taxa as well as their evolutionary history still remain unresolved. The role of fossils in a phylogenetic framework is pivotal in understanding some of the evolutionary processes that led to chalcidoid megadiversity and provide valuable information on morphological character evolution (Donoghue et al., 1989; Peters et al., 2018). Reliably placed fossils can shed light on the minimum age of taxa and allow calibrations of molecular phylogenies to resolve timing and patterns of biological shifts (Ware \& Barden, 2016; Gunkel et al., 2017; Slater, Harmon \& Alfaro, 2012).

Numerous chalcidoid fossils have been reported from different amber deposits (Grimaldi \& Engel, 2005; Penney, 2010), but few of them have been formally described. Most described chalcidoids stem from young (Eocene and Miocene) deposits, which already host an astonishing phylogenetic diversity of taxa (Darling, 1996; Gibson, 2008, 2009, 2013; Engel, 2009; Engel, McKellar \& Huber, 2013; Heraty \& Darling, 2009; Compton et al., 2010; McKellar \& 
51 Engel, 2012; Krogmann, 2013; Simutnik, Perkovsky \& Gumovsky, 2014; Bläser, Krogmann \& 52 Peters, 2015; Burks et al., 2015; Farache et al., 2016). It is believed that most chalcidoid families diversified after the Upper Cretaceous (Heraty et al., 2013; Peters et al. 2018) during a period that falls within a major gap in the chalcidoid fossil record, from which only few taxa have been described or even discovered (Burks et al. 2015; Heraty \& Darling, 2009; Penney, 2010). The earliest reported and described chalcidoids date back to the Lower Cretaceous period, 106-115 million years ago (mya) (Kaddumi, 2005; Grimaldi \& Engel, 2005; Penney, 2010; Barling, Heads \& Martill, 2013).

The fossil Minutoma yathribi Kaddumi, 2005 is currently the oldest described putative chalcidoid wasp from Jordanian amber, dated about 115 million years old (myo) (Kaddumi, 2005). It was placed in Mymaridae, which is considered to be the sister group to all other chalcidoid families (Heraty et al., 2013). Heraty et al. (2013) however commented, that the photo of $M$. yathribi rather suggests affiliation with Bouceklytinae, an extinct subfamily of uncertain placement. Kaddumi (2005) also mentioned a putative eupelmid fossil, which was not formally described. The family assignment of the concerned fossil is questionable as the metasomal and wing venational characters depicted in Kaddumi (2005, figs 95-97) are characteristic for Scelioninae (Platygastridae) (own observation). Myanmymar aresconoides Poinar \& Huber, 2011 represents the oldest verified fossil record of Chalcidoidea, dating back to the Early Upper Cretaceous, approximately 99 mya (Shi et al., 2012). Although there are some reports of Eulophidae and Chalcididae from the transition between the Upper and Lower Cretaceous, no information concerning their validity is available (Penney, 2010).

Schmidt et al. (2010) reported Eulophidae, Trichogrammatidae and Mymaridae from Ethiopian amber, which they dated through chemical and spectroscopic methods to an Upper Cretaceous origin (around 94 mya). Though the family identifications might be right, doubt was raised concerning the age of Ethiopian amber. Coty, Lebon \& Nel (2016) described a myrmecine ant from the same deposit, which could readily be described in the tribe Crematogastrini, suggesting through phylogenetic dating that the specimen cannot be of Cretaceous age. Subsequent revised gas chromatography and infrared spectroscopy analyses showed, that indeed, though not completely unequivocal, evidence strongly suggested that Ethiopian amber is of Cenozoic origin, probably at least 50 million years younger than formerly suspected (Coty, Lebon \& Nel, 2016). Currently, the oldest verified record of the families Trichogrammatidae and Aphelinidae are from Baltic amber, approximately 44 myo (Burks et al., 2015).

From the Upper Cretaceous Canadian amber ( 75 myo), fossil Tetracampidae and Trichogrammatidae were recorded by Yoshimoto (1975). Of the four genera described by Yoshimoto (1975) within Mymaridae (Carpenteriana, Macalpinia, Protooctonus and Triadomerus), Protooctonus was later transferred to Mymarommatidae and synonymized under Archaeromma Yoshimoto, 1975 (Gibson, Read \& Huber, 2007). Enneagmus Yoshimoto, 1975, originally described within Trichogrammatidae, was transferred by Huber (2005) to Mymaridae. The placement of Distylopus, Bouceklytus and Baeomorpha within Tetracampidae by Yoshimoto (1975) was considered erroneous and even the position of Distylopus within Chalcidoidea was presumed unlikely as stated by Gumovsky \& Perkovsky (2005) and Heraty \& Darling (2009). 
After a recent revision, Distylopus and Bouceklytus are now regarded as Chalcidoidea incertae sedis and Baeomorpha and its respective subfamily Baeomorphinae were transferred to Rotoitidae (Gumovsky, Perkovsky \& Rasnitsyn 2018). McKellar \& Engel (2012) additionally mention Torymidae and Eupelmidae as possibly present in Canadian amber, although the specimens have not been thoroughly studied to date.

A putative member of Pteromalidae, Parviformosus wohlrabeae Barling, Heads \& Martill, 2013, was described from limestone originating from the Crato formation, dated to the Aptian period, about 110 mya. Because of its age, it might be considered as one of the oldest known fossils of Chalcidoidea, but evidence for its placement is ambiguous because none of the diagnostic features of Chalcidoidea was preserved (Barling, Heads \& Martill, 2013; Farache et al., 2016). It was placed within Pteromalidae only because of a putative habitus resemblance to Sycophaginae (now Agaonidae sensu Heraty et al., 2013). The limited morphological characters of $P$. wohlrabeae need to be reassessed before phylogenetic conclusions can be drawn from this fossil. The original placement of $P$. wohlrabeae in Pteromalidae is in this case highly problematic, because the family, in its current concept, is indicated to be polyphyletic (Campbell et al., 2000; Krogmann \& Vilhelmsen, 2006; Heraty et al., 2013).

We here contribute to the scarce Cretaceous fossil record of Chalcidoidea by describing three new fossil genera and species within a new family. These fossils lack synapomorphies with any of the currently described chalcidoid families, but possess many putatively plesiomorphic features, suggesting a basal position within Chalcidoidea.

\section{Material \& Methods}

\section{Specimens}

Four specimens in four different pieces of Burmese amber were examined. Burmese amber is of Upper Cretaceous origin, approximately 99 my old (Shi et al., 2012). Additional information about the geographical origin of the individual pieces is not known. All pieces are deposited in the amber collection of the State Museum of Natural History, Stuttgart, Germany (SMNS). Imaging Imaging was done, using a MZ 16 APO Leica ${ }^{\circledR}$ microscope, with an attached DXM 1200 Leica $^{\circledR}$ camera. The images were generated by stacking single images using the Automontage ${ }^{\circledR}$ technique and the program Helicon Focus Pro ${ }^{\circledR}$ (Vers. 6.7.1). For additional and detail imaging as well as measurements the digital microscopes Keyence VHX 600 and VHX 5000 were used. Adobe Photoshop ${ }^{\circledR}$ CS4 Version: 11.0.2 was used to process all images. Drawings were made, using a camera lucida on a Leica ${ }^{\circledR}$ M205 C microscope. Digitalization of the drawings and arrangement of the image plates was done with Adobe Illustrator ${ }^{\circledR}$ CS4 Version: 14.0.0.

\section{Terminology}

Terminology follows the Hymenoptera Anatomy Ontology (HAO) (Yoder et al., 2010). Abbreviations listed in Table 1 are used throughout the text and illustrations.

\section{Cladistic analysis}


131 Morphological cladistic analyses were performed using the 233 characters from Heraty et al.

132 (2013). Their comprehensive matrix, encompassing 19 families, 78 subfamilies, 268 genera and 133283 species of Chalcidoidea was used as basis for the here conducted phylogenetic analysis.

134 Due to conservation state and inaccessibility, some characters could not be scored for the 135 fossils without reasonable doubt and were marked as unknown "?" (Appendix S1). Analyses 136 were conducted using the program TNT ver. 1.5 (Goloboff, Farris \& Nixon, 2008) following 137 Heraty et al. (2013) in analysis setup. A sectorial search, with equally weighted characters, 138 under New Technology methods was performed, using a ratchet weighting probability of 5\% 139 with 50 iterations, tree-drifting of 50 cycles, tree-fusing of five rounds and a best score hit of 10

140

141

142

143

144

145

146

147

148

149

150

151

152

153

154

155

156

157

158

159

160

161

162

163

164

165

166

167

168

169 times. New Technology searches in TNT provide refined algorithms more effective than simple branch swapping techniques applied in traditional searches, leading to shorter analyze times, especially in large datasets (Goloboff, Farris \& Nixon, 2008). Nevertheless, traditional searches with and without implied weighting were conducted as well to test consistency of the results. Dependent on the used concavity constant (k), implied weighting aims to decrease the phylogenetic impact of supposed homoplasious characters, in comparison to equal weighting, (Congreve \& Lamsdell, 2016). Morphological datasets of Chalcidoidea are reported to include a multitude of potentially homoplasious characters (Krogmann \& Vilhelmsen, 2006; Heraty et al., 2013), therefore implied weights of $k=1,3,5,10,15,20,25,30,35,40,45,50,55$, and 60 were used with 1000 replications and Tree Bisection and Re-connection (TBR) for the analyses.

\section{Nomenclature}

The electronic version of this article in Portable Document Format (PDF) will represent a published work according to the International Commission on Zoological Nomenclature (ICZN), and hence the new names contained in the electronic version are effectively published under that Code from the electronic edition alone. This published work and the nomenclatural acts it contains have been registered in ZooBank, the online registration system for the ICZN. The ZooBank LSIDs (Life Science Identifiers) can be resolved and the associated information viewed through any standard web browser by appending the LSID to the prefix http://zoobank.org/. The LSID for this publication is: LSID urn:Isid:zoobank.org:pub:B936D52D-7165-47CE-9C3E0B79A17AC5AC. The online version of this work is archived and available from the following digital repositories: PeerJ, PubMed Central and CLOCKSS.

\section{Results}

\section{Systematic Palaeontology}

Diversinitidae fam. $\mathbf{n}$.

LSID urn:Isid:zoobank.org:act:017E601E-FB88-4821-8EA7-16228EC61C37

Type genus. Diversinitus gen. $\mathrm{n}$. 
Diagnosis. Antenna 13-segmented in male (Figs. 1B-D, 2A, 3A and 3B) and female (Figs. 4C, 4E and $5 \mathrm{~A}$ ), with eight funiculars and 3-segmented clava, including a distinct terminal button; all funiculars (including F1) with multiporous plate sensilla (Figs. 1C, 4C and 4E). Eyes large, without pilosity, inner margins not divergent ventrally (Figs. 1B and 4B). Occipital carina absent. Labrum exposed below clypeus (Figs. 1B and 4B), semicircular, flap-like with setae at least at apical margin, broadly contiguous with clypeal margin. Mandibles two toothed (Figs. $2 \mathrm{~A}$ and 3A). Pronotum lacking collar (Figs. 3A, 5A and 5B). Mesosoma with independent, large and triangular, laterally exposed prepectus (Figs. 3A, 5A and 5B). Mesothoracic spiracle situated at lateral margin of mesoscutum, at juncture of pronotum and prepectus. Mesonotum with notauli deep and complete (Figs. 1D, 3B, 5A and 5B). Mesoscutellum with frenum distinguishable (Figs. 1D, 3B and 4F). Mesopleuron concave with acropleuron not enlarged. Fore wing with short marginal fringe. Basal vein at least apically pigmented (Figs. 1E and 4A). Uncus elongate, bent in direction of postmarginal vein (Figs. 1E, 4A and 4D). Postmarginal vein distinctly longer than marginal vein (Figs. 1E, 4A and 4D). Hind wing normal, membrane extending to base of wing, three hamuli, first straight (Figs. $1 \mathrm{E}$ and $4 \mathrm{~A}$ ). Tibial spur formula 1:1:2; protibial spur slightly curved, slender, simple tip; mesotibial spur slender and straight. Tarsus on all legs five segmented. Metasoma with $\mathrm{Mt}_{8}$ and $\mathrm{Mt}_{9}$ fused into syntergum $\left(\mathrm{Mt}_{8+9}\right)$ in both sexes (Figs. 3A, 3B, 5A and 5B). Cercus peg-like (Figs. 3A, 5A and 5B).

\section{Key to species of Diversinitidae}

1. Head distinctly towering over mesosoma (Fig. 4A). Pronotum almost as long as mesoscutum (Figs. 4A and 5A). Basal cell bare, basal vein nearly completely pigmented (Figs. 2A, 4A). Ovipositor protruding about half the length of gaster (Fig. 4A). [only female known]

\section{Burminata caputaeria}

- Head only slightly towering over mesosoma (Figs. 2A, 2B and 4D). Pronotum short, about $1 / 4$ length of mesoscutum (Figs. $1 \mathrm{~A}$ and $4 \mathrm{G}$ ) Basal cell pilose (Fig. 1E), basal vein only apically pigmented (Fig. 2B). Ovipositor only slightly protruding gaster (Fig. 4D).

\section{2.}

2. Gaster sessile (Fig. 4D). Mouthmargin surrounded by long setae (Figs. 4D and 5B). Antenna inserted at about center of face, with toruli closer to each other than to margin of eye. Axilla advanced almost 1/4 length of mesoscutum (Fig. 4G). Speculum on forewing present (Fig. 4 D). Protibia with a row of stout setae on anterior margin. [only female known]

\section{Glabiala barbata}

- Gaster distinctly petiolate (Figs. 1A and 1D). Mouthmargin not surrounded by long setae (Fig. 1B). Antenna inserted in lower third of face, with toruli closer to eye margin than to each other (Fig. 1B). Axilla not advanced (Fig. 1D). Speculum on forewing absent (Fig. 1E). Protibia without row of stout setae on anterior margin. [only males known]

\section{Diversinitus attenboroughi}

\section{Diversinitus gen. $\mathbf{n}$.}


210

211

212

213

214

215

216

217

218

219

220

221

222

223

224

225

226

227

228

229

230

231

232

233

234

235

236

237

238

239

240

241

242

243

244

245

246

247

248

249

LSID urn:Isid:zoobank.org:act:F8B422B0-C83B-4718-8042-D7F07EA0DF7F

Type species. Diversinitus attenboroughi sp. n.

Diagnosis. Antenna inserted in lower third of face (Fig. 1B). Clypeus transverse. Scape ventrally expanded (Figs. 2A and 3A). Pronotum less than 1/4 length of mesoscutum (Figs. 1D and 3B). Axilla not advanced. Frenum anteriorly delimited by deep frenal groove (Figs. 1D and 3A). Fore wing completely pilose, i.e. speculum absent (Fig. 1E), basal vein only anteriorly pigmented. Gaster distinctly petiolate (Fig. 1D).

Etymology. The generic name Diversinitus is composed of two parts. The first being "Divers-", originating from the Latin adjective "diversus", meaning diverse or different. The second part, "initus", is the Latin noun "initus" translating to "origin" or "start". Together the two parts can be translated to "origin of diversity", referring to the age of the fossil and the diversity which evolved since its appearance in the Upper Cretaceous. The generic name is masculine in gender.

Diversinitus attenboroughi sp. n. (Figs. 1-3)

LSID urn:Isid:zoobank.org:act:3840E4D4-46A6-4192-8052-20E561DD913F

Diagnosis. As for the genus.

Male. Measurements: $(h)=$ holotype, $(p)$ = paratype. Total body length, excluding protruded aedeagus $1.67 \mathrm{~mm}(\mathrm{~h})$, metasoma of paratype destroyed.

Head. In frontal view oval, bare, broader than rest of body, breadth $0.41(\mathrm{p})-0.52 \mathrm{~mm}$ (h), height $0.34 \mathrm{~mm}(\mathrm{~h})$, length in dorsal view $0.23(\mathrm{p})-0.29 \mathrm{~mm}(\mathrm{~h})$. Foramen magnum situated higher than half height of head. Eye length $0.25 \mathrm{~mm}(\mathrm{~h})$, height $0.28 \mathrm{~mm}(\mathrm{~h})$, distance between eyes 0.21 (p)-0.23 mm (h). Transfacial sulcus indiscernible. Antennal scrobes probably shallow. Clypeus transverse, apically truncate, tentorial pits absent, dorsal margin straight. Mandible at least two times as long as broad with slight curvature and few short setae on outer surface. Maxillary palps with at least three segments. Labial palps with at least two segments. Malar space shorter than $1 / 3$ length of an eye.

Antenna. Inserted in lower third of face, hardly above ventral level of eyes, with toruli closer to edge of eyes than to each other. Scape ventrally expanded and broadened over most of its length, not reaching median ocellus. Pedicel length, measured laterally, $0.05(h)-0.06$ $\mathrm{mm}(\mathrm{p})$ and breadth $0.04 \mathrm{~mm}(\mathrm{~h}, \mathrm{p})$. F1 subquadrate, fully developed (not anelliform); following funiculars increasingly more transverse and broadening distally, F1 - F4 with sides diverging (subconical), F5 - F8 more parallel sided (cylindrical) and asymmetrically formed, connections between segments rather slanted; F1 dorsolateral length $(\mathrm{mm})$ : width $(\mathrm{mm})=0.03(\mathrm{p})-0.04(\mathrm{~h})$ : $0.03(p)-0.04(h), F 2=0.02(h, p): 0.04(h, p), F 3=0.02(p)-0.03(h): 0.04(h, p), F 4=0.2(p)-0.03$ (h): $0.04(h, p), F 5=0.03(h, p): 0.04(h, p), F 6=0.03(h, p): 0.04(h, p), F 7=0.03(p, h): 0.04(p)-$ $0.05(h), F 8=0.03(p)-0.04(h): 0.04(p)-0.05(h)$. Clava differentiated, sutures rather straight; 
250

251

252

253

254

255

256

257

258

259

260

261

262

263

264

265

266

267

268

269

270

271

272

273

274

275

276

277

278

279

280

281

282

283

284

285

286

287

288

289

290

F9 length $(\mathrm{mm})$ : width $(\mathrm{mm})=0.03(h, p): 0.04(p)-0.05(h), F 10=0.02(h, p): 0.03(p)-0.04(h)$, $\mathrm{F} 11+\mathrm{F} 12=0.02(\mathrm{p})-0.04(\mathrm{~h}): 0.02(\mathrm{p})-0.03(\mathrm{~h})$.

Mesosoma. Length $0.60(p)-0.74 \mathrm{~mm}(\mathrm{~h})$, arched. Pronotum bare, posteriorly deeply emarginated, u-shaped, medially much shorter $(0.06(p)-0.07 \mathrm{~mm}(\mathrm{~h}))$ than mesoscutum $(0.25$ (p) $-0.27 \mathrm{~mm}(\mathrm{~h}))$, regularly reticulate. Prepectus slightly convex, lightly sculptured, with thin shiny rim along its dorsal and posterior margin. Tegula much smaller than prepectus. Mesonotum finely regularly reticulate and with very sparse, short pilosity. Mesoscutum slightly shorter than wide; notauli reaching transscutal articulation, widely separated posteriorly. Mesoscutellum length $0.23(\mathrm{p})-0.26 \mathrm{~mm}(\mathrm{~h})$, with frenum delimited anteriorly by deep frenal groove (length: 0.05 (p)-0.06 $\mathrm{mm}(\mathrm{h})$ ); axillae not advanced, widely separated at transscutal articulation. Metapleuron small, bare. Metanotum length 0.06 (p)-0.07 mm (h), with smooth metascutellum not reaching anterior margin of metanotum, lateral panel foveolate. Propodeum transverse, rectangular, slightly arched, length $0.09(p)-0.11 \mathrm{~mm}(\mathrm{~h})$, with coarse irregular sculpture, lateral propodeal callus bare; spiracles round to slightly elliptical.

Wings. Fore wing hyaline, immaculate, entirely pilose; humeral plate with at least three setae; basal vein apically pigmented and angled relative to submarginal vein at about $10-15^{\circ}$; marginal vein slightly thickened relative to postmarginal vein; stigmal vein about 0.5 times length of marginal vein; uncus bent at angle of about $95-100^{\circ}$ in direction of postmarginal vein, almost reaching it; postmarginal vein not reaching apex of wing, 1.5 times as long as marginal vein. Hind wing apical 2/3 pilose, rest relatively bare; posterior marginal fringe moderately long.

Legs. Pro- and metacoxa larger than mesocoxa; metacoxa dorsally bare, except few hairs posteriorly. Protibial setae inconspicuous and short. Basitarsal comb not visible. Metatibia laterally flattened, bearing two spurs, one robust, the other short and more slender.

Metasoma. Petiole ( $\mathrm{Mt}_{1}$ ) cylindrical distinct and reticulate, length $0.09 \mathrm{~mm}(\mathrm{~h})$, breadth $0.06 \mathrm{~mm}(\mathrm{~h})$. Gaster of holotype $0.66 \mathrm{~mm}$ in length, lanceolate; terga smooth and bare except of $\mathrm{Mt}_{6}-\mathrm{Mt}_{8+9}$ with longitudinal rugosity and lateral setae, hindmargins straight, length of terga of holotype: $\mathrm{Mt}_{2}: 0.24 \mathrm{~mm}, \mathrm{Mt}_{3}: 0.07 \mathrm{~mm}, \mathrm{Mt}_{4}: 0.07 \mathrm{~mm}, \mathrm{Mt}_{5}: 0.07 \mathrm{~mm}, \mathrm{Mt}_{6}: 0.11 \mathrm{~mm}, \mathrm{Mt}_{7}$ : $0.06 \mathrm{~mm}, \mathrm{Mt}_{8+9}: 0.04 \mathrm{~mm}$. Cerci peg-like with few long setae.

Female. Unknown.

Specimen examined. Male holo- (SMNS Bu-4) and paratype (SMNS Bu-5) deposited in the SMNS. The amber piece hosting the holotype also includes syninclusions: three complete Diptera and three further Diptera, which are preserved only in part. Additionally, a Serphitidae (Hymenoptera) is included in the same piece. The amber piece including the paratype also hosts a Platygastridae: Scelioninae (Hymenoptera).

Etymology. Named after the well renowned British broadcaster and naturalist Sir David Frederick Attenborough for his inspiring enthusiasm and devotion to natural sciences. This species was dedicated to Sir Attenborough during his visit to the SMNS on the occasion of his $91^{\text {st }}$ birthday.

\section{Burminata gen. nov.}

LSID urn:Isid:zoobank.org:act:71D5E586-8406-486A-85AC-FA5CA1F293D8 
291

292

293

294

295

296

297

298

299

300

301

302

303

304

305

306

307

308

309

310

311

312

313

314

315

316

317

318

319

320

321

322

323

324

325

326

327

328

329

330

331

Type species. Burminata caputaeria sp. $\mathrm{n}$.

Diagnosis. Foramen magnum situated at lower third of head (Fig. 4A). Tentorial pits deep (Fig. 4B). Clypeus transverse (Fig. 4B). Pronotum only slightly shorter than mesoscutum (Fig. 5A). Axilla slightly advanced (Fig. 5A). Fore wing with speculum; basal cell bare; basal vein almost completely pigmented (Fig. 4A). Posterior fringe on hind wing long (Fig. 4A). Ovipositor protruding about half length of gaster (Fig. 4A).

Etymology. The generic name is composed of two parts. The first part "Burmi-", references the origin of the amber piece whereas the second part, "-nata", originates from the Latin adjective "natus" translating to "born". The generic name is feminine in gender.

Burminata caputaeria sp. n. (Fig. 4A-C and Fig. 5A)

LSID urn:Isid:zoobank.org:act:AA5C051D-90AB-4D21-80F1-90AE82A8125A

Diagnosis. As for the genus.

Female. Total body length, excluding protruding ovipositor $1.23 \mathrm{~mm}$.

Head. In frontal view oval, bare, much broader than rest of body, breadth $0.40 \mathrm{~mm}$, height $0.23 \mathrm{~mm}$, dorsal length not measurable. Foramen magnum situated at lower third of head. Eye length $0.17 \mathrm{~mm}$, height $0.16 \mathrm{~mm}$, distance between eyes $0.22 \mathrm{~mm}$. Putative transfacial sulcus anterior to antennal scrobes length $0.10 \mathrm{~mm}$. Antennal scrobes absent. Clypeus transverse, apically truncate, laterally delimited by large tentorial pits, dorsal margin straight. Mandible about 1.6 times as long as broad, rather straight, setae not distinguishable. Maxillary palps with at least three segments. Labial palp segments not countable. Malar space more than $1 / 3$ length of an eye.

Antenna. Inserted at about center of face, at half height of eyes, with toruli slightly closer to edge of eyes than to each other. Scape slender, not flattened, not reaching median ocellus. Pedicel length, measured laterally, $0.04 \mathrm{~mm}$ and breadth $0.04 \mathrm{~mm}$. F1 subquadrate, subconical, fully developed (not anelliform); following funiculars transverse to quadrate, conical, connections between segments rather slanted; F1 lateral length $(\mathrm{mm})$ : width $(\mathrm{mm})=$ 0.03: 0.04, F2 = 0.03: 0.04, F3 = 0.03: 0.04, F4 = 0.04: 0.04, F5 = 0.04: 0.04, F6 = 0.04: 0.04, F7 = 0.04: $0.04, F 8=0.04: 0.04$. Clava differentiated, sutures oblique, F9 length $(\mathrm{mm}):$ width $(\mathrm{mm})=$ 0.04: 0.04, F10 = 0.03: 0.04, F11 + F12 = 0.03: 0.03 .

Mesosoma. Length $0.49 \mathrm{~mm}$, weakly arched. Pronotum bare except of few long setae on hind margin, posteriorly slightly emarginated, medially only slightly shorter $(0.12 \mathrm{~mm})$ than mesoscutum $(0.15 \mathrm{~mm})$, regularly finely reticulate. Prepectus convex, lightly sculptured, with thin shiny rim along its dorsal and posterior margin. Tegula much smaller than prepectus. Mesonotum, finely regularly reticulate, largely bare, only few single setae on lateral lobe of mesoscutum, msoscutellum and axilla. Mesoscutum breadth not measurable; notauli reaching transscutal articulation, widely separated posteriorly. Mesoscutellum length $0.14 \mathrm{~mm}$, with frenum short $(0.02 \mathrm{~mm})$, delimited anteriorly by shallow frenal groove; axillae slightly 
332

333

334

335

336

337

338

339

340

341

342

343

344

345

346

347

348

349

350

351

352

353

354

355

356

357

358

359

360

361

362

363

364

365

366

367

368

369

370

371

advanced, widely separated at transscutal articulation. Metapleuron small and triangular, bare. Metanotum and propodeum hardly discernable because of cracked amber and air inclusions, propodeum apparently arched.

Wings. Fore wing hyaline, immaculate, speculum present, basal cell bare, costal cell pilose throughout; humeral plate with at least two setae; basal vein almost completely pigmented, angled relative to submarginal vein at about $27^{\circ}$; marginal vein as thick as postmarginal vein; stigmal vein about 0.4 times length of marginal vein; uncus bent at angle of about $110^{\circ}$ in direction of postmarginal vein, almost reaching it; postmarginal vein not reaching apex of wing, 1.6 times as long as marginal vein. Hind wing apical 2/3 pilose, rest relatively bare; posterior marginal fringe long.

Legs. Pro- and mesocoxa about same size, metacoxa slightly larger, dorsally completely bare. Protibial setae inconspicuous and short. Basitarsal comb not visible. Metatibia hardly flattened, bearing two equally short and robust spurs.

Metasoma. Petiole ( $\left.\mathrm{Mt}_{1}\right)$ indistinct. Gaster lanceolate, length excluding ovipositor 0.52 $\mathrm{mm}$; terga smooth and bare except dorsal surface of $\mathrm{Mt}_{7}$ and $\mathrm{Mt}_{8+9}$ with longitudinal rugosity, hindmargins straight, length of terga: $\mathrm{Mt}_{2}: 0.12 \mathrm{~mm}, \mathrm{Mt}_{3}: 0.04 \mathrm{~mm}, \mathrm{Mt}_{4}: 0.04 \mathrm{~mm}, \mathrm{Mt}_{5}: 0.05$ $\mathrm{mm}, \mathrm{Mt}_{6}: 0.06 \mathrm{~mm}, \mathrm{Mt}_{7}: 0.11 \mathrm{~mm}, \mathrm{Mt}_{8+9}: 0.09 \mathrm{~mm}$. Cercus peg-like, appearing to be slightly spatulate, arising from under syntergum, bearing at least three setae. Hypopygium folded downwards, slightly longer than half of gaster. Ovipositor protruding about half length of gaster, third valvulae broad.

Male. Unknown.

Specimen examined. The holotype (SMNS Bu-304) is deposited in the SMNS. Besides the holotype the amber piece also includes two Diptera and one Platygastridae: Scelioninae (Hymenoptera), amongst parts of other insects.

Etymology. The specific epithet "caputaeria" consists of two parts originating from the Latin noun for "head" (caput) and adjective "towering up" (aerius), referring to the lowly situated foramen magnum, leaving the head protruding especially high over the pronotum. The species name is treated as an adjective.

\section{Glabiala gen. nov.}

LSID urn:Isid:zoobank.org:act:10644623-4534-4848-B961-1E608CBB773B

\section{Type species. Glabiala barbata sp. $\mathrm{n}$.}

Diagnosis. Head densely pilose, with mouth margin surrounded by especially long setae (Figs. 4D and 5B). Clypeus quadrate. Toruli situated at about center of face, closer to each other than to margin of eyes. All funiculars rather thistle shaped (Fig. 4E). Pronotum and mesonotum with dense, short pilosity (Fig. 4F). Pronotum about $1 / 3$ the length of the mesoscutum (Figs. $4 G$ and 5B). Axillae advanced about $1 / 4$ the length of the mesoscutum (Fig. 4G). Frenum large, delimited by deep frenal groove (Fig. 4F). Lateral propodeal callus with dense pilosity. Fore wing 
372

373

374

375

376

377

378

379

380

381

382

383

384

385

386

387

388

389

390

391

392

393

394

395

396

397

398

399

400

401

402

403

404

405

406

407

408

409

410

411

with speculum (Fig. 4D); basal cell pilose, basal vein only anteriorly pigmented. Metacoxa dorsally with short pilosity. Ovipositor hardly protruding apex of gaster (Fig. 4D).

Etymology. The name consists of two parts originating from the Latin words for "hairless" (glabellus) and "wing" (ala), referring to the distinct speculum on the wing of the specimen. The generic name is feminine in gender.

Glabiala barbata sp. n. (Fig. 4D-G and Fig. 5B)

LSID urn:Isid:zoobank.org:act:01C89C3D-E207-4544-A5AD-3BA80EFE61CB

Diagnosis. As for the genus.

Female. Total body length, excluding protruding ovipositor: $2.21 \mathrm{~mm}$.

Head. Frontal view largely blocked, appearing trapezoid, finely pilose, except quite long pilosity on gena and mouth margin, about as broad as body, actual breadth and height not measurable. Foramen magnum situated higher than half height of head. Eye length $0.23 \mathrm{~mm}$, height $0.27 \mathrm{~mm}$, distance between eyes not measurable. Transfacial sulcus not discernable. Antennal scrobes absent. Clypeus quadrate with subparallel sides, apically truncate, tentorial pits absent, dorsal margin straight. Mandible not measurable, appearing broad and straight, with numerous longer setae on its outer surface. Maxillary palps probably with four segments. Labial palps with at least two segments. Malar space about $1 / 3$ length of an eye.

Antenna. Inserted at about center of face (direct frontal view blocked), slightly below half height of eyes, with toruli closer to each other than to eyes. Scape slightly broadened, not reaching median ocellus. Pedicel lateral length not assessable. F1 subconical fully developed (not anelliform), distal funiculars more transverse, F2 - F8 appearing thistle-shaped, with F2 F7 asymmetrically shaped, connections between segments rather slanted; F1 lateral length $(\mathrm{mm})$ : width $(\mathrm{mm})=0.05: 0.05, \mathrm{~F} 2=0.06: 0.05, \mathrm{~F} 3=0.05: 0.05, \mathrm{~F} 4=0.06: 0.05, \mathrm{~F} 5=0.05: 0.05$, $\mathrm{F} 6=0.05: 0.06, F 7=0.05: 0.06, F 8=0.05: 0.06$. Clava not clearly differentiated, segments separated by deep, rather straight sutures, F9 length $(\mathrm{mm})$ : width $(\mathrm{mm})=0.04: 0.05, \mathrm{~F} 10=$ 0.05: 0.05, F11 + F12 = 0.05: 0.04.

Mesosoma. Length $0.96 \mathrm{~mm}$, weakly arched. Pronotum densely shortly pilose, posteriorly deeply emarginated, u-shaped, medially much shorter $(0.12 \mathrm{~mm})$ than mesoscutum $(0.4 \mathrm{~mm})$, regularly reticulate. Prepectus almost flat, lightly sculptured, view on rim not clear. Tegula smaller than prepectus. Mesonotum regularly reticulate and densely, shortly pilose. Mesoscutum about 2/3 as long as wide; notauli reaching transscutal articulation, widely separated posteriorly. Mesoscutellum length $0.31 \mathrm{~mm}$, with frenum delimited anteriorly by deep frenal groove (length: $0.07 \mathrm{~mm}$ ); axillae strongly advanced, about 1/4 length of mesoscutum, widely separated at transscutal articulation. Metapleuron small and triangular, with few scattered setae. Metanotum length $0.06 \mathrm{~mm}$, with smooth metascutellum not reaching anterior margin of metanotum, lateral panels prominent, foveolate. Propodeum transverse, rectangular, relatively flat, length $0.11 \mathrm{~mm}$, reticulation regular, lateral propodeal callus with dense and long pilosity; spiracles round to slightly elliptical. 
412

413

414

415

416

417

418

419

420

421

422

423

424

425

426

427

428

429

430

431

432

433

434

435

436

437

438

439

440

441

442

443

444

445

446

447

448

449

450

451

452

Wings. Fore wing hyaline, immaculate, speculum present, basal cell pilose, costal cell pilose throughout; humeral plate with at least two setae; basal vein apically pigmented and angled relative to submarginal vein at about $9^{\circ}$; marginal vein slightly thickened relative to postmarginal vein; stigmal vein about 0.4 times length of marginal vein; uncus bent at angle of about $95^{\circ}$ in direction of postmarginal vein, almost reaching it; postmarginal vein not reaching apex of wing, 1.6 times as long as marginal vein. Hind wing apical 1/2 densely pilose, the rest relatively bare; posterior marginal fringe short.

Legs. Pro-, meso- and metacoxa about same size, metacoxa dorsally with short pilosity. Protibia with stout setae on anterior margin, other setae more inconspicuous. Basitarsal comb longitudinal. Metatibia laterally flattened bearing two slender spurs, subequal in length.

Metasoma. Petiole ( $\left.\mathrm{Mt}_{1}\right)$ indistinct. Gaster lanceolate, length excluding ovipositor 0.98 $\mathrm{mm}$; terga smooth and bare, hindmargins straight, length of terga: $\mathrm{Mt}_{2}: 0.21 \mathrm{~mm}, \mathrm{Mt}_{3}: 0.09$ $\mathrm{mm}, \mathrm{Mt}_{4}: 0.15 \mathrm{~mm}, \mathrm{Mt}_{5}: 0.18 \mathrm{~mm}, \mathrm{Mt}_{6}: 0.14 \mathrm{~mm}, \mathrm{Mt}_{7}: 0.11 \mathrm{~mm}, \mathrm{Mt}_{8+9}: 0.1 \mathrm{~mm}$. Cercus peglike, club-shaped, arising from under syntergum, bearing at least three setae. Hypopygium folded downwards, slightly longer than $2 / 3$ of the gaster. Ovipositor protruding about length of $\mathrm{Mt}_{8+9}$, third valvulae broad.

Male. Unknown

Specimen examined. Female holotype (SMNS Bu-303) deposited in the SMNS. The piece of amber was cut to reveal a better view of the specimen. Both pieces are free of other inclusions. Etymology. The specific epithet "barbata" is the feminine form of the adjective "barbatus" which means "bearded" and refers to the setose lower face of the specimen. The species name treated as an adjective.

\section{Taxonomic remarks:}

It may seem counterintuitive to place the only two known males of Diversinitidae in a separate genus than the two females, especially since sexual dimorphism is widely spread in Chalcidoidea, most notably in Agaonidae and Eupelmidae resulting in a separation of sexes in morphological analysis of females and males, when coded separately (Krogmann \& Vilhelmsen, 2006; Heraty et al. 2013). In most other chalcidoids however, those modifications do not include severe changes to the body plan and are often confined to body size (Hurlbutt, 1987) and antennal characters (Barlin \& Vinson, 1981). Males of $D$. attenboroughi differ from both known females of Diversinitidae by the absence of a speculum on the forewing (versus presence of speculum), an elongate petiole (versus a transverse petiole) and an antennal insertion in the lower $1 / 3$ of the face (versus an insertion near center of face). In addition, they also lack each of the diagnostic characters of the other two females (see below) so that a separate generic placement seems to be justified.

Furthermore, we consider the two females as not congeneric based on significant morphological differences: Glabiala barbata differs from B. caputaeria in having the foramen magnum situated higher than half the height of the head (versus lower third of head), a pronotum only $1 / 3$ length of mesoscutum (versus slightly shorter than mesoscutum), distinctly advanced axillae (versus slightly advanced), a large and clearly anteriorly delimited frenum 
453 (versus short and shallowly delimited) and a pilose basal cell on the forewing (versus a bare 454 basal cell).

455

456

457

458

459

460

461

462

463

464

465

466

467

468

469

470

471

472

473

474

475

476

477

478

479

480

481

482

483

484

485

486

487

488

489

490

491

492

\section{Results of cladistics analyses}

The new technology analysis in TNT found 39 most parsimonious trees (5,395 steps) with the strict consensus tree being 5,861 steps long. The general topology of Heraty et al. (2013) could largely be retrieved (Fig. 6). As in Heraty et al. (2013) the following families appeared as monophyletic: Agaonidae, Chalcididae, Encyrtidae, Eurytomidae, Leucospidae, Mymaridae, Rotoitidae, Signiphoridae, Torymidae (including Megastigminae) and Trichogrammatidae. Contrary to Heraty et al. (2013), Aphelinidae and Eucharitidae could be retrieved as monophyletic as well. In the unweighted new technology analysis Mymarommatoidea was nested within Chalcidoidea as part of a larger clade containing the chalcidoid families Aphelinidae, Mymaridae, Rotoitidae and Signiphoridae, as well as few members of Tetracampidae and Eulophidae. Leucospidae were recovered as sistergroup to all other Chalcidoidea, including Mymarommatoidea. The fossils were recovered as a monophyletic group with Micradelus rotundus Walker, 1834 as sister taxon, nested within a large polytomy. Monophyly of the fossils could be retrieved in all analyses, however general tree topology changed considerably between different analyses. Using a traditional search without implied weighting (Appendix S2), Diversinitidae were recovered as sistergroup of all other Chalcidoidea with the inclusion of Mymarommatoidea. Mymaridae as well as Rotoitidae clustered in deeper clades far from the base of the tree. Using a traditional search with implied weights (Appendix S2), Mymarommatoidea were almost always recovered as sistergroup of Chalcidoidea (except $k$ $=45$ ), but topology changed drastically with increasing $\mathrm{k}$ value, as did the position of the fossils within the tree. In most analyses with $\mathrm{k}$ values below 30 , the fossils were closely affiliated with the pteromalid genera Habritys brevicornis (Ratzeburg, 1844), Cheiropachus quadrum (Fabricius, 1787) and other interchanging groups. Above a $\mathrm{k}$ of 30, M. rotundus was recovered as a sistertaxon ( $k=35$ and 55 ) or only Cheiropachus quadrum $(k=40)$, Diversinitidae were sister to all Chalcidoidea including Mymarommatoidea $(k=45)$ or they were recovered close to Platynocheilus cuprifrons (Nees, 1834) and some Ormocerinae ( $\mathrm{k}=50$ and 60).

\section{Discussion}

The placement of Diversinitidae within Chalcidoidea is well supported by several morphological synapomorphies. One of the key autapomorphies of Chalcidoidea are the structurally unique multiporous plate sensilla (mps) on the antennal funicle, with their apices free of their surrounding antennal cuticle, the lack of an encircling groove around the sensillum and elevation of the multiporous plate above the antennal cuticular level (Barlin \& Vinson, 1981; Gibson, 1986; Basibuyuk \& Quicke, 1999). Evidently, Diversinitidae have modified sensilla (Figs. 1C, 4C and 4E), which are raised above the antennal surface and have their apices not completely surrounded by the antennal cuticle. Some mps, although not all, even protrude slightly over the funicular apices, as seen with backlighting under high magnification. The lack of an encircling groove cannot be unequivocally confirmed, but overall resemblance to mps of 
493

494

495

496

497

498

499

500

501

502

503

504

505

506

507

508

509

510

511

512

513

514

515

516

517

518

519

520

521

522

523

524

525

526

527

528

529

530

531

532

533

other Chalcidoidea is apparent. Within those groups of Proctotrupomorpha that are most closely related to Chalcidoidea (Peters et al., 2017), few possess mps on their antennae. Only Cynipoidea and the family Pelecinidae within Proctotrupoidea share this feature, but show a quite different sensillar morphology with their sensillae usually only slightly raised above the antennal surface and possessing a groove surrounding the multiporous plate (Basibuyuk \& Quicke, 1999). Other Proctotrupoidea, Ceraphronoidea, Platygastroidea and Diaprioidea possess setiform multiporous sensilla sharing little resemblance with the morphology of chalcidoid mps (Gibson, 1986; Basibuyuk \& Quicke, 1999). Even Mymarommatidae, the putative sister group of Chalcidoidea, lack mps (Gibson, 1986; Munro et al., 2011; Heraty et al., 2013).

Another diagnostic feature of Chalcidoidea is the presence of a free, externally visible prepectus between the pronotum and mesopleuron, which separates the pronotum from the tegula (Gibson, 1985, 1999; Gibson, Heraty \& Woolley, 1999). Diversinitidae have a large triangular prepectus, neither fused to the pronotum or mesopleuron nor hidden beneath its lateral margin (Figs. 3A, 4A, 5A and 5B). Additionally, like in other chalcidoids, the mesothoracic spiracle is situated between the lateral margin of the mesoscutum and the pronotum directly adjacent to the anterodorsal edge of the prepectus, another autapomorphy of Chalcidoidea that is correlated with its external prepectus. Gibson (1999) hypothesized the more dorsal position of the spiracle compared to other hymenopterans as a derived state. Other hymenopterans having a concealed prepectus or a prepectus that is fused either to the pronotum or mesopleuron have the spiracle originating somewhat more ventrally below the level of the mesoscutum between the pronotum and mesepisternum. In Rotoitidae and Mymaridae, the spiracle is situated between the lateral margin of the mesoscutum and the pronotum, but in Rotoitidae and some Mymaridae the prepectus is slender and more or less concealed under the pronotum. Mymaridae and Rotoitidae are hypothesized as basalmost clades within Chalcidoidea (Gibson, 1986; Munro, 2011; Heraty et al. 2013; Peters et al. 2018) and their prepectal structure may represent a transitional state (Gibson, 1999).

Assignment of the fossils to extant chalcidoid families is not possible due to the lack of synapomorphies. The most prominent characteristic of Diversinitidae separating them from all other chalcidoid families, except for some Mymaridae, is the possession of mps on the first flagellomere (F1) in both sexes. Mps on F1 is found in Chalcidoidea only in very few cases. In Mymaridae, most males possess mps on their first flagellomere and also females of very few species (e.g., within the genera Eustochomorpha Girault 1915 and Yoshimotoana Huber, 2015) have them (Heraty et al., 2013; Huber, 2015, 2017). Some Aphelininae (Aphelinidae) and Eucharitidae also seemingly possess mps on their apparent F1, but this is only because the first two flagellomeres are fused (Heraty et al., 2013). In Diversinitidae, the first visible flagellomere is undoubtedly F1 in both sexes. A well-developed F1 that has mps is hypothesized as plesiomorphic for Chalcidoidea (Heraty et al., 2013), suggesting a basal position of Diversinitidae within Chalcidoidea. During the evolution of Chalcidoidea, the first funicular likely secondarily lost mps in association with the segment being reduced in length to a ring-like segment (anellus) as is suggested by some chalcidoids that have additional funiculars reduced to anelli-like segments that lack mps. In those, comparatively few chalcidoids with F1 lacking 
$534 \mathrm{mps}$ but being reduced in size, F1 is hypothesized to have been secondarily lengthened (see 535 character 11 in Gibson, 2003).

536 Burminata caputaeria is the only species in Diversinitidae possessing a discernible line 537 above the scrobal area, corresponding in position and size to a transfacial sulcus (Fig. 4B). A 538 transfacial sulcus or transfacial line, situated below the anterior ocellus right above the 539 antennal scrobes, is found in many, mostly soft-bodied families including Aphelinidae, 540 Encyrtidae, Eulophidae, Eupelmidae (only Phenaceupelmus Gibson, 1995), Pteromalidae, 541 Tetracampidae and Trichogrammatidae (Gibson, 1986, 1995; Burks et al., 2011; Kim \& Heraty, 542 2012; Heraty et al., 2013). This transfacial sulcus is structurally different from the trabeculae of 543 Mymaridae, which are formed by several interconnected lines of cuticular invaginations, 544 separating the vertex as a distinct sclerite from the face and are therefore regarded as autapomorphic for this family (Königsmann, 1978; Schauff, 1984; Gibson, 1986). Rotoitidae as well as Mymarommatidae lack any indication of a transfacial sulcus (Bouček \& Noyes, 1987; Gibson \& Huber, 2000; Huber et al., 2008), leaving the ground plan of this character for Chalcidoidea uncertain.

The labrum of Diversinitidae can be described as free, semicircular or rectangular, flaplike and broadly continuous with the clypeal margin. Darling (1988) postulated, that the ground plan structure of the labrum for Chalcidoidea is flap-like, with many evenly distributed setae. Darling (1988) referred to the labrum of Chalcididae as "remarkably uniform and [...] similar to that hypothesized as the ground plan for Apocrita", being heavily sclerotized and contiguous with the margin of the clypeus, bearing long, tapered setae on the entire surface, arising from distinct sockets. In Pteromalidae, the plesiomorphic state of the labrum is found in Cleonyminae, and the labrum is also exposed in Spalangiinae, Asaphinae, Eunotinae and others, which bear in comparison to Cleonyminae setae only along their apical margin (Darling, 1988). Some Mymaridae also possess an exposed labrum (Heraty et al., 2013; Huber, 2013).In Diversinitidae, the setal pattern is difficult to assess due to refractions within the amber in conjunction with the small size of the specimens. Setae are at least situated along the apical margin in Diversinitidae, but whether they are also found on the surface remains uncertain. If so, the labrum might also be putatively plesiomorphic for Diversinitidae.

Diversinitidae possess a bidentate mandible, which is widely distributed in Chalcidoidea, although a three or more dentate mandible appears to be more common (Bouček \& Noyes, 1987; Woolley, 1988; Dzhanokmen, 1996; Gibson, Heraty \& Woolley, 1999; Gibson \& Huber, 2000; Heraty et al., 2013). The plesiomorphic state for this character is not known and has so far not been discussed for Chalcidoidea comprehensively so that the evolutionary patterns are difficult to assess. Putatively basal chalcidoid families already exhibit varied states of mandible dentation, with Rotoitidae having bidentate mandibles, of which Chiloe micropteron Gibson and Huber, 2000 has the upper tooth finely serrated (Bouček \& Noyes, 1987; Gibson \& Huber,

571 2000). Denticulation in Mymaridae varies greatly, with taxa lacking mandibular teeth

572 (Erythmelus rosascostai Ogloblin, 1934) to taxa with many fine denticles (Eubroncus spp.)

573 (Heraty et al., 2013; Jin \& Li, 2014). The mymarid genera Triadomerus Yoshimoto, 1975

574 (extinct), Macalpinia Yoshimoto, 1975 (extinct) and Neotriadomerus Huber, 2017 (extant) are 
575

576

577

578

579

580

581

582

583

584

585

586

587

588

589

590

591

592

593

594

595

596

597

598

599

600

601

602

603

604

605

606

607

608

609

610

611

612

613

614

615

considered to be the most basal taxa in this family (Huber, 2017). In those early groups mandibular dentation is already differing, with bidentate mandibles in Triadomerus and Macalpinia and four uneven teeth in Neotriadomerus, hampering phylogenetic implications. Outgroup comparisons with Mymarommatoidea and other Proctotrupomorpha (sensu Peters et al., 2017) reveal that also in those groups, mandibular dentation is highly variable (Naumann \& Masner, 1985), not permitting a stable hypothesis about the groundplan state for Chalcidoidea. However, Diversinitidae as putative basal group within Chalcidoidea might indicate that bidentate mandibles could be plesiomorphic for at least a smaller subset of chalcidoid taxa.

A frenum is found in Diversinitidae, which is likely a plesiomorphic character state for Chalcidoidea (Krogmann \& Vilhelmsen, 2006). Presence is observed in many chalcidoid families and in closely related groups, such as Mymarommatidae, Diapriidae and Platygastridae: Scelioninae (Heraty et al., 2013), suggesting that it is probably part of the ground plan structure for a subgroup of Proctotrupomorpha. Frenal morphology is used in species and subfamily distinction of Torymidae and Pteromalidae (Graham, 1969; Graham \& Gijswijt, 1998; Gibson, 2003). The morphological variation of the frenum led to frequent discussions about its homology between different taxonomic groups (Grissell, 1995; Gibson, Heraty \& Woolley, 1999; Vilhelmsen \& Krogmann, 2006).

Diversinitidae possess peg-like cerci, which are more or less spatulate. This character state has been considered as plesiomorphic in contrast to a button-like cercus (Gibson, 2003) or, alternatively, as an apomorphic character state, which has independently evolved in different chalcidoid groups (Grissell, 1995). Grissell (1995) postulated that though peg-like cerci are found in Agaonidae sensu lato, Eulophidae (Entia Hedqvist, 1974), Pteromalidae (Cea Walker, 1837 and Chromeurytoma Cameron, 1912), Torymidae and Megastigmidae, evolution of this character must have been convergent because positioning of the cerci is different in those groups. On the other hand, Gibson (2003) stated that many other groups have peg-like cerci as well, though most often not as prominent as those listed above, and therefore he considered exerted, basally articulated cerci as plesiomorphic relative to more reduced, platelike cerci. In Heraty et al. (2013) many taxa were also coded as possessing exerted cerci to various degrees, such as Perilampidae (Brachyelatus sp.), Tetracampidae (Platynocheilus sp.), Signiphoridae (Signiphora sp.), Mymaridae (Borneomymar sp.) and Tanaostigmatidae (Protanaostigma sp.). Outgroup comparison for this character in Heraty et al. (2013) is however not conclusive due to sparse taxon sampling. Mymarommatidae (Mymaromella sp.) was coded as not possessing exerted cerci, compared to Scelioninae (Archaeoteleia mellea Masner, 1968), which show slightly exerted cerci and Diapriidae (Belyta sp.) without coding for this character. The wide distribution of peg-like cerci within Chalcidoidea and its appearance in Mymaridae and Diversinitidae supports the hypothesis that they represent the plesiomorphic state over button-like cerci.

Presenting a solid phylogenetic placement of Diversinitidae within Chalcidoidea is not unequivocally possible. All cladistic analyses provided evidence for monophyly of Diversinitidae, but did not resolve further relationships within Chalcidoidea, because placement of the fossils and general tree topology remained highly variable between different analysis. Although 
616 Micradelus rotundus was recovered as sister taxon of Diversinitidae in the new technology 617 analysis and few traditional searches with implied weighting, a true relationship is highly 618 doubtful. Micradelus rotundus belongs to the pteromalid subfamily Pireninae. This subfamily is 619 characterized, though not only, by a reduced number of antennal segments and at least one 620 annellus (Bouček, 1988), which is also the most prominent difference to Diversinitidae, sharing 621 little resemblance to $M$. rotundus aside from morphologically variable characters like a 622 bidentate mandible, lack of pronotal collar, deep notauli or exposed labrum. Additionally 623 placement of $M$. rotundus was inconsistent over the different analyses and it behaved like a 624 rogue taxon, jumping between several clades. However, high inconsistencies in the analyses 625 were expected, because the morphology-only analysis in Heraty et al. (2013) was also poorly 626 resolved. Due to the expected high rate of homoplasious characters in morphological datasets 627 of Chalcidoidea (Krogmann \& Vilhelmsen, 2006; Heraty et al., 2013), especially the results from 628 analyses with and without implied weighting differed considerably. With increasing $k$ values, 629 the base of the phylogenetic tree was mostly relatively well resolved. Mymmarommatoidea 630 were the sistergroup to Chalcidoidea and Rotoitidae and Mymaridae were retrieved as basal 631 lineages within the superfamily. However, changes in topology of higher relationships were 632 substantial. Through weighing down putative homoplasious characters, implied weighting is 633 capable of better resolving polytomies (Goloboff et al. 2008). This can lead to trees with more correctly resolved clades, but also higher risks of erroneous placements and more inconsistent topologies as demonstrated by Congreve \& Lamsdell (2016). Implied weighting can therefore be considered as less conservative over equal weighing of characters. There are conflicting views on whether parsimony analyses (Goloboff, Torres \& Arias, 2017), as conducted in this study, or likelihood analyses (O'Reilly et al. 2017) perform better with morphological datasets. A comparison between likelihood and parsimony methods performed by Heraty et al. (2013) on the original dataset, however, resulted in a generally congruent tree with equally poor resolution of taxa. Additionally, probabilistic methods infer an evolutionary model on the data, based on subjective decisions and previous knowledge (Goloboff, Torres \& Arias, 2017). We therefore favored the conservative equal weight parsimony analysis over implied weighting and likelihood analyses.

Unfortunately, there is no evident autapomorphic character of Diversinitidae, which would support its monophyly and all characters that exclude this group from existing families are seemingly plesiomorphic (see above). However, based on the unique combination of morphological characters (see diagnosis) and the preliminary results from the cladistic analyses (Fig. 6), we decided to place the new fossils into their own family rather than leaving them unplaced within Chalcidoidea.

Morphologically, Diversinitidae appear to be an early lineage of Chalcidoidea, possessing many putatively plesiomorphic characters (see discussion above). Mymaridae are thought to form the sister group to all remaining Chalcidoidea and can be traced back at least to the mid654 Cretaceous (Gibson, 1986; Munro et al., 2011; Heraty et al., 2013). Resemblance between 655 Diversinitidae and Mymaridae is not obvious and they only possess few putatively 656 symplesiomorphic characters, such as an exposed labrum and mps on the true F1 in males and 
657

658

659

660

661

662

663

664

665

666

667

668

669

670

671

672

673

674

675

676

677

678

679

680

681

682

683

684

685

686

687

688

689

690

691

692

693

694

695

696

some females. In general, the mymarid body plan is characterized by a number of derived autapomorphies that have not changed much since the Mid Cretaceous (Poinar \& Huber, 2011). The phylogenetic position of Diversinitidae can therefore not be established with certainty and several hypotheses are possible. Firstly, Diversinitidae could represent the sister group to all remaining chalcidoids, since they show a multitude of plesiomorphic characters, foremost mps on F1. During chalcidoid evolution mps on F1 might have been lost at first in females (as in most Mymaridae) and subsequently also in males (as in all remaining Chalcidoidea). This would imply, that the prepectus in Diversinitidae was either secondarily enlarged or that Mymaridae and Rotoitidae reduced the prepectal size during their evolution. Diversinitidae might also represent a sistergroup to a smaller subset of Chalcidoidea, suggesting that mps on F1 were independently lost at least twice, once in most females in Mymaridae and once in all other Chalcidoidea. Prepectal size might therefore have been increased in other Chalcidoidea relative to the prepectus in Mymaridae and Rotoitidae.

Biological implications of the new fossils are difficult to draw, because their phylogenetic position is not fully resolved. Egg parasitoidism is hypothesized to be the putative ground plan biology of Chalcidoidea (Heraty et al., 2013, Peters et al., 2018). Diversinitidae share a relatively small body size, which unites nearly all egg parasitizing taxa, but does not necessarily exclude ectoparasitoid groups. Body shape is not indicative, because both ecto- and endoparasitoids can be very diverse in this regard. The length of the ovipositor and its saw-like tip might be indicative for concealed hosts inside plant material.

\section{Conclusion}

With the newly described fossils we reduce a significant fossil gap of Chalcidoidea from the Cretaceous. The wasp species described herein provide important new information of chalcidoid evolution because they are early representatives of a parasitoid lineage that was just beginning to evolve. One hundred million years later we merely start to fully appreciate the great morphological diversity and ecological significance of these "green myriads in the peopled grass" (Walker, 1839), which still rank among the least known of all insects. Further Cretaceous fossils will hopefully reduce the fossil gap even further to help us to understand how chalcidoid wasps have evolved and shaped the evolution of their arthropod host groups and associated plant species, as one of the most diverse and influential insect groups that life has ever seen.

\section{Acknowledgements}

We thank Patrick Müller (Käshofen, Germany) for the kind donation of the holotype of Burminata caputaeria and Karin Wolf-Schwenninger (SMNS) for providing access to the amber collection and for technical support.

\section{References}

Barlin MR., Vinson SB. 1981. Multiporous plate sensilla in antennae of the chalcidoidea (Hymenoptera). International Journal of Insect Morphology and Embryology 10:29-42. 
697

698

699

700

701

702

703

704

705

706

707

708

709

710

711

712

713

714

715

716

717

718

719

720

721

722

723

724

725

726

727

728

729

730

731

732

733

DOI: 10.1016/0020-7322(81)90011-8.

Barling N., Heads SW., Martill DM. 2013. A new parasitoid wasp (Hymenoptera: Chalcidoidea) from the Lower Cretaceous Crato Formation of Brazil: The first Mesozoic Pteromalidae. Cretaceous Research 45:258-264. DOI: 10.1016/j.cretres.2013.05.001.

Basibuyuk HH., Quicke DL. 1999. Gross morphology of multiporous plate sensilla in the Hymenoptera (Insecta). Zoologica Scripta 28:51-67. DOI: 10.1046/j.14636409.1999.00007.x.

Bläser M., Krogmann L., Peters RS. 2015. Two new fossil genera and species of Cerocephalinae (Hymenoptera, Chalcidoidea, Pteromalidae), including the first record from the Eocene. ZooKeys 545:89-100. DOI: 10.3897/zookeys.545.6470.

Bouček Z., Noyes JS. 1987. Rotoitidae, a curious new family of Chalcidoidea (Hymenoptera) from New Zealand. Systematic Entomology 12:407-412. DOI: 10.1111/j.13653113.1987.tb00212.x.

Bouček Z. 1988. Australasian Chalcidoidea (Hymenoptera). A biosystematic revision of genera of fourteen families, with a reclassification of species. CAB International, Wallingford, Oxon, U.K., Cambrian News Ltd; Aberystwyth, Wales.

Burks RA., Heraty JM., Gebiola M., Hansson C. 2011. Combined molecular and morphological phylogeny of Eulophidae (Hymenoptera: Chalcidoidea), with focus on the subfamily Entedoninae. Cladistics 27:581-605. DOI: 10.1111/j.1096-0031.2011.00358.x.

Burks RA., Heraty JM., Pinto JD., Grimaldi D. 2015. Small but not ephemeral: Newly discovered species of Aphelinidae and Trichogrammatidae (Insecta: Hymenoptera: Chalcidoidea) from Eocene amber. Systematic Entomology 40:592-605. DOI: 10.1111/syen.12124.

Campbell B., Heraty JM., Rasplus J-Y., Chan K., Steffen-Campbell J., Babcock C. 2000. Molecular systematics of the Chalcidoidea using 28S-D rDNA. In: Austin AD., Dowton M eds. Hymenoptera: evolution, biodiversity and biological control. Fourth International Hymenoptera Conference, held in Canberra, Australia, in January 1999. Collingwood, Australia: CSIRO, 59-73.

Compton SG., Ball AD., Collinson ME., Hayes P., Rasnitsyn AP., Ross AJ. 2010. Ancient fig wasps indicate at least $34 \mathrm{Myr}$ of stasis in their mutualism with fig trees. Biology letters 6:838842. DOI: $10.1098 / \mathrm{rsbl} .2010 .0389$.

Congreve CR., Lamsdell JC. 2016. Implied weighting and its utility in palaeontological datasets: A study using modelled phylogenetic matrices. Palaeontology 59:447-462. DOI: 10.1111/pala.12236.

Coty D., Lebon M., Nel A. 2016. When phylogeny meets geology and chemistry: doubts on the dating of Ethiopian amber. Annales de la Société entomologique de France (N.S.) 52:161166. DOI: 10.1080/00379271.2016.1230477.

Darling DC. 1988. Comparative morphology of the labrum in Hymenoptera: the digitate labrum 
734

735

736

737

738

739

740

741

742

743

744

745

746

747

748

749

750

751

752

753

754

755

756

757

758

759

760

761

762

763

764

765

766

767

768

769

770

of Perilampidae and Eucharitidae (Chalcidoidea). Canadian Journal of Zoology 66:28112835. DOI: 10.1139/z88-409.

Darling DC. 1996. A new species of Spalangiopelta (Hymenoptera; Pteromalidae; Ceinae) from Dominican Amber: Phylogenetic and Biogeographic Implications. Journal of Kansas Entomological Society 69:248-259.

Donoghue MJ., Doyle JA., Gauthier J., Kluge AG., Rowe T. 1989. The Importance of Fossils in Phylogeny Reconstruction. Annual Review of Ecology and Systematics 20:431-460. DOI: 10.1146/annurev.es.20.110189.002243.

Dzhanokmen KA. 1996. Morphology of Mouthparts in Chalcids (Hymenoptera, Pteromalidae). Entomological Review 76:547-552.

Engel M. 2009. The first fossil leptofoenine wasp (Hymenoptera, Pteromalidae): A new species of Leptofoenus in Miocene amber from the Dominican Republic. ZooKeys 13:57-66. DOI: 10.3897/zookeys.13.159.

Engel MS., McKellar RC., Huber JT. 2013. A fossil species of the primitive mymarid genus Borneomymar (Hymenoptera: Mymaridae) in Eocene Baltic amber. Novitates Paleoentomologicae 5:1-8. DOI: 10.17161/np.v0i5.4651.

Farache FHA., Rasplus J-Y., Azar D., Pereira RAS., Compton SG. 2016. First record of a nonpollinating fig wasp (Hymenoptera: Sycophaginae) from Dominican amber, with estimation of the size of its host figs. Journal of Natural History 50:2237-2247. DOI: 10.1080/00222933.2016.1193646.

Gibson GAP. 1985. Some Pro- and Mesothoracic Structures Important for Phylogenetic Analysis of Hymenoptera, With a Review of Terms Used for the Structures. The Canadian Entomologist 117:1395-1443. DOI: 10.4039/Ent1171395-11.

Gibson GAP. 1986. Evidence for monophyly and relationships of Chalcidoidea, Mymaridae and Mymarommatidae (Hymenoptera: Terebrantes). The Canadian Entomologist 118:205-240. DOI: 10.4039/Ent118205-3.

Gibson GAP. 1995. Parasitic wasps of the subfamily Eupelminae: classification and revision of world genera (Hymenoptera: Chalcidoidea: Eupelmidae). Memoirs on entomology international 5:1-421.

Gibson GAP. 1999. Sister-group relationships of the Platygastroidea and Chalcidoidea (Hymenoptera) - an alternate hypothesis to Rasnitsyn (1988). Zoologica Scripta 28:125138. DOI: 10.1046/j.1463-6409.1999.00015.x.

Gibson GAP. 2003. Phylogenetics and classification of Cleonyminae (Hymenoptera: Chalcidoidea: Pteromalidae). Memoirs on Entomology, International 16:100-101.

Gibson GAP. 2008. Description of Leptoomus janzeni, n. gen. and n. sp. (Hymenoptera: Chalcidoidea) from Baltic amber, and discussion of its relationships and classification relative to Eupelmidae, Tanaostigmatidae and Encyrtidae. Zootaxa 1730:1-26. 
771

772

773

774

775

776

777

778

779

780

781

782

783

784

785

786

787

788

789

790

791

792

793

794

795

796

797

798

799

800

801

802

803

804

805

806

807

Gibson GAP. 2009. Description of three new genera and four new species of Neanastatinae (Hymenoptera, Eupelmidae) from Baltic amber, with discussion of their relationships to extant taxa. ZooKeys 20:175-214. DOI: 10.3897/ zookeys.20.161.

Gibson GAP. 2013. The extinct Baltic amber genus Propelma Trjapitzin, a valid genus of Neanastatinae (Hymenoptera, Eupelmidae). ZooKeys 283:59-69. DOI: 10.3897/zookeys.283.4665.

Gibson GAP., Heraty JM., Woolley JB. 1999. Phylogenetics and classification of Chalcidoidea and Mymarommatoidea - a review of current concepts (Hymenoptera, Apocrita). Zoologica Scripta 28:87-124. DOI: 10.1046/j.1463-6409.1999.00016.x.

Gibson GAP., Huber JT. 2000. Review of the family Rotoitidae (Hymenoptera: Chalcidoidea), with description of a new genus and species from Chile. Journal of Natural History 34:2293-2314. DOI: 10.1080/002229300750037901.Gibson GAP., Read J., Huber JT. 2007. Diversity, classification and higher relationships of Mymarommatoidea (Hymenoptera). Journal of Hymenoptera Research 16:51-146.

Goloboff PA., Farris JS., Nixon KC. 2008. TNT, a free program for phylogenetic analysis. Cladistics 24:774-786. DOI: 10.1111/j.1096-0031.2008.00217.x.

Goloboff PA., Carpenter JM., Arias JS., Rafael D., Esquivel, Rafael M. 2008. Weighting against homoplasy improves phylogenetic analysis of morphological data sets. Cladistics 24:1-16. DOI: 10.1111/j.1096-0031.2008.00209.x.

Goloboff PA., Torres A., Arias JS. 2017. Weighted parsimony outperforms other methods of phylogenetic inference under models appropriate for morphology. Cladistics. DOI: 10.1111/cla.12205.

Graham MW. 1969. The Pteromalidae of North- Western Europe the British Museum (Natural History). Bulletin of the British Museum (Natural History) Entomology Suppl. 16:1-909.

Graham MDV., Gijswijt M. 1998. Revision of the European species of Torymus Dalman (s. lat.) (Hymenoptera: Torymidae). Zoologische Verhandelingen 317:1-202.

Grimaldi D., Engel MS. 2005. Evolution of the Insects. Cambridge: Cambridge University Press.

Grissell EE. 1995. Toryminae (Hymenoptera: Chalcidoidea: Torymidae): a redefinition, generic classification and annotated world catalogue of species. Memoirs on entomology international 2:1-474.

Gumovsky A., Perkovsky E. 2005. Taxonomic notes on Tetracampidae (Hymenoptera: Chalcidoidea) with description of a new fossil species of Dipricocampe from Rovno amber. Entomological Problems 35:123-130.

Gumovsky A., Perkovsky E., Rasnitsyn A. 2018. Laurasian ancestors and "Gondwanan" descendants of Rotoitidae (Hymenoptera: Chalcidoidea): What a review of Late Cretaceous Baeomorpha revealed. Cretaceous Research 84:286-322. DOI: 10.1016/j.cretres.2017.10.027. 
808

809

810

811

812

813

814

815

816

817

818

819

820

821

822

823

824

825

826

827

828

829

830

831

832

833

834

835

836

837

838

839

840

841

842

843

844

Gunkel S., Rust J., Wappler T., Mayer C., Niehuis O., Misof B. 2017. A posteriori evaluation of molecular divergence dates using empirical estimates of time-heterogenous fossilization rates. bioRxiv. DOI: 10.1101/128314.

Heraty JM. 2009. Parasitoid biodiversity and insect pest management. In: Foottit, B., Adler, $P$. (Eds.), Insect Biodiversity: Science and Society. Hague, Netherlands: Springer-Verlag Press, 445-462.

Heraty JM., Burks RA., Cruaud A., Gibson GAP., Liljeblad J., Munro J., Rasplus J-Y., Delvare G., Janšta P., Gumovsky A., Huber J., Woolley JB., Krogmann L., Heydon S., Polaszek A., Schmidt S., Darling DC., Gates MW., Mottern J., Murray E., Dal Molin A., Triapitsyn S., Baur H., Pinto JD., van Noort S., George J., Yoder M. 2013. A phylogenetic analysis of the megadiverse Chalcidoidea (Hymenoptera). Cladistics 29:466-542. DOI: 10.1111/cla.12006.

Heraty JM., Darling DC. 2009. Fossil Eucharitidae and Perilampidae (Hymenoptera: Chalcidoidea) from Baltic Amber. Zootaxa 16:1-16.

Heraty JM., Gates ME. 2001. Diversity of Chalcidoidea (Hymenoptera) at El Edén Reserve, Mexico. In: In: Gómez-Pompa, A., Allen, M.F., Fedick, S.L., R.C. McKellar, M.S. Engel / Cretaceous Research 35 (2012) 258e279 277 Jiménez-Osornio, J.J. (Eds.), Proceedings of the 21st Symposium in Plant Biology, "Lowland Maya Area: Three Millenia at the HumanWildland Interface". Haworth Press, New York, NY. 277-292.

Huber JT. 2005. The gender and derivation of genus-group names in Mymaridae and Mymarommatidae ( Hymenoptera ). Acta Societatis Zoologicae Bohemicae 69:167-183.

Huber JT. 2013. Revision of Ooctonus in the Neotropical region and comparison with Boudiennyia (Hymenoptera: Mymaridae). Zootaxa 3701:1-23. DOI: 10.11646/zootaxa.3701.1.1

Huber JT. 2015. World reclassification of the Gonatocerus group of genera (Hymenoptera: Mymaridae). Zootaxa 3967:1. DOI: 10.11646/zootaxa.3967.1.1.

Huber JT. 2017. Eustochomorpha Girault, Neotriadomerus gen. n., and Proarescon gen. n. (Hymenoptera, Mymaridae), early extant lineages in evolution of the family. Journal of Hymenoptera Research 57:1-87. DOI: 10.3897/jhr.57.12892.

Huber JT., Gibson GAP., Bauer LS., Liu H., Gates MW. 2008. The Genus Mymaromella (Hymenoptera: Mymarommatidae) in North America, with a Key to Described Extant Species. Journal of Hymenoptera Research 17:175-194.

Hurlbutt B. 1987. Sexual size dimorphism in parasitoid wasps. Biological Journal of the Linnean Society 30:63-89. DOI: 10.1111/j.1095-8312.1987.tb00290.x.

Jin X-X., Li C-D. 2014. First record of Eubroncus (Hymenoptera, Mymaridae) from China, with description of three new species. ZooKeys 399:29-41. DOI: 10.3897/zookeys.399.6996.

Kaddumi HF. 2005. Amber of Jordan The Oldest Prehistoric Insects in Fossilized Resin. Publications of the Eternal River Museum of Natural History, Amman. 
845

846

847

848

849

850

851

852

853

854

855

856

857

858

859

860

861

862

863

864

865

866

867

868

869

870

871

872

873

874

875

876

877

878

879

880

881

Kim JW., Heraty JM. 2012. A phylogenetic analysis of the genera of Aphelininae (Hymenoptera: Aphelinidae), with a generic key and descriptions of new taxa. DOI: 10.1111/j.13653113.2012.00625.x.

Königsmann E. 1978. Das phylogenetische System der Hymenoptera Teil 3: "Terebrantes" (Unterordnung Apocrita). Deutsche Entomologische Zeitschrift 25:1-55. DOI: 10.1002/mmnd.19780250102.

Krogmann L. 2013. First fossil record of cerocephaline wasps with a description of a new genus and species from Dominican amber (Hymenoptera: Chalcidoidea: Pteromalidae: Cerocephalinae). Historical Biology 25:43-49. DOI: 10.1080/08912963.2012.685729.

Krogmann L., Vilhelmsen L. 2006. Phylogenetic implications of the mesosomal skeleton in Chalcidoidea (Hymenoptera, Apocrita) - Tree searches in a jungle of homoplasy. Invertebrate Systematics 20:615-674. DOI: 10.1071/IS06012.

McKellar RC., Engel MS. 2012. Hymenoptera in Canadian Cretaceous amber (Insecta). Cretaceous Research 35:258-279. DOI: 10.1016/j.cretres.2011.12.009.

Munro JB., Heraty JM., Burks RA., Hawks D., Mottern J., Cruaud A., Rasplus J-Y., Jansta P. 2011. A Molecular Phylogeny of the Chalcidoidea (Hymenoptera). PLoS ONE 6:e27023. DOI: 10.1371/journal.pone.0027023.

Noyes JS. 1978. On the numbers of genera and species of Chalcidoidea (Hymenoptera) in the World. Entomologist's Gazette 29:163-164.

Noyes JS. 2000. Encyrtidae of Costa Rica (Hymenoptera: Chalcidoidea), Part 1: The Subfamily Tetracneminae, Parasitoids of Mealybugs (Homoptera: Pseudococcidae). Memoirs of the Entomological Institute 62.

Noyes JS. 2017. Universal Chalcidoidea Database. Available at http://www.nhm.ac.uk/chalcidoids (accessed 24 November 2017).

O’Reilly JE., Puttick MN., Pisani D., Donoghue PCJ. 2018. Probabilistic methods surpass parsimony when assessing clade support in phylogenetic analyses of discrete morphological data. Palaeontology 61:105-118. DOI: 10.1111/pala.12330.

Penney D. 2010. Biodiversity of fossils in amber from the major world deposits. Siri Scientific Press.

Peters RS., Krogmann L., Mayer C., Donath A., Gunkel S., Meusemann K., Kozlov A., Podsiadlowski L., Petersen M., Lanfear R., Diez PA., Heraty J., Kjer KM., Klopfstein S., Meier R., Polidori C., Schmitt T., Liu S., Zhou X., Wappler T., Rust J., Misof B., Niehuis O. 2017. Evolutionary History of the Hymenoptera. Current Biology 27:1013-1018. DOI: 10.1016/j.cub.2017.01.027.

Peters RS., Niehuis O., Gunkel S., Bläser M., Mayer C., Podsiadlowski L., Kozlov A., Donath A., van Noort S., Liu S., Zhou X., Misof B., Heraty J., Krogmann L. 2018. Transcriptome sequence-based phylogeny of chalcidoid wasps (Hymenoptera: Chalcidoidea) reveals a 
882

883

884

885

886

887

888

889

890

891

892

893

894

895

896

897

898

899

900

901

902

903

904

905

906

907

908

909

910

911

912

913

914

915

history of rapid radiations, convergence, and evolutionary success. Molecular Phylogenetics and Evolution 120:286-296. DOI: 10.1016/j.ympev.2017.12.005.

Poinar G., Huber JT. 2011. A new genus of fossil mymaridae (Hymenoptera) from cretaceous amber and key to cretaceous mymarid genera. ZooKeys 130:461-472. DOI: 10.3897/zookeys.130.1241.

Schauff ME. 1984. The Holarctic genera of Mymaridae (Hymenoptera: Chalcidoidea). Memoirs of the Entomological Society of Washington 12:1-67.

Schmidt AR., Perrichot V., Svojtka M., Anderson KB., Belete KH., Bussert R., Dörfelt H., Jancke S., Mohr B., Mohrmann E., Nascimbene PC., Nel A., Nel P., Ragazzi E., Roghi G., Saupe EE., Schmidt K., Schneider H., Selden PA., Vávra N. 2010. Cretaceous African life captured in amber. Proceedings of the National Academy of Sciences of the United States of America 107:7329-7334. DOI: 10.1073/pnas.1000948107.

Shi G., Grimaldi DA., Harlow GE., Wang J., Wang J., Yang M., Lei W., Li Q., Li X. 2012. Age constraint on Burmese amber based on U-Pb dating of zircons. Cretaceous Research 37:155-163. DOI: 10.1016/j.cretres.2012.03.014.

Simutnik SA., Perkovsky EE., Gumovsky AV. 2014. Review of the Late Eocene Encyrtidae (Hymenoptera, Chalcidoidea) with a description of the first fossil genus with filum spinosum. Paleontological Journal 48:65-73. DOI: 10.1134/S0031030114010122.

Slater GJ., Harmon L., Alfaro ME. 2012. Integrating fossils with molecular phylogenies improves inferences of trait evolution. Evolution 66:3931-3944. DOI: 10.5061/dryad.q96d7.

Vilhelmsen L., Krogmann L. 2006. Skeletal anatomy of the mesosoma of Palaeomymar anomalum (Blood \& Kryger, 1922)(Hymenoptera: Mymarommatidae). Journal of Hymenoptera Research 15:290-306.

Walker F. 1839. Monographia Chalcidium I. London: Hyppolitus Baillière.

Ware JL., Barden P. 2016. Incorporating fossils into hypotheses of insect phylogeny. Current Opinion in Insect Science 18:69-76. DOI: 10.1016/j.cois.2016.10.003.

Weiblen GD. 2002. How to be a fig wasp. Annual Review of Entomology 47:299-330.

Woolley JB. 1988. Phylogeny and classification of the Signiphoridae (Hymenoptera: Chalcidoidea). Systematic Entomology 13:465-501. DOI: 10.1111/j.13653113.1988.tb00256.x.

Yoder MJ., Mikó I., Seltmann KC., Bertone MA., Deans AR. 2010. A Gross Anatomy Ontology for Hymenoptera. PLoS ONE 5:e15991. DOI: 10.1371/journal.pone.0015991.

Yoshimoto CM. 1975. Cretaceous chalcidoid fossils from canadian amber. The Canadian Entomologist 107:499-528. 


\section{Table $\mathbf{1}$ (on next page)}

Abbreviations for morphological structures.

HAO-Numbers inserted in the following link $(*)$ provide direct access to referenced structures in the HAO database (http://purl.obolibrary.org/obo/*). 


\begin{tabular}{|c|c|c|}
\hline Abbreviation & Morphological structure & HAO-Number \\
\hline ax & Axilla & HAO_0000155 \\
\hline bv & Basal vein & HAO_0000170 \\
\hline cer & Cercus & HAO_0000191 \\
\hline $\mathrm{CX}_{1}$ & Procoxa & HAO_0001122 \\
\hline $\mathrm{Cx}_{2}$ & Mesocoxa & HAO_0000635 \\
\hline $\mathrm{Cx}_{3}$ & Metacoxa & HAO_0000587 \\
\hline F1-12 & Flagellomeres 1-12 & HAO_0000342 \\
\hline frn & Frenum & HAO_0000355 \\
\hline $\mathrm{lbr}$ & Labrum & HAO_0000456 \\
\hline $\mathrm{mps}$ & Multiporous plate sensillum & HAO_0000640 \\
\hline msc & Mesoscutum & HAO_0000575 \\
\hline Mt & Metasomal tergite & HAO_0002005 \\
\hline $\mathrm{Mt}_{8+9}$ & Syntergum & HAO_0000987 \\
\hline $\mathrm{no}_{1}$ & Pronotum & HAO_0000853 \\
\hline $\mathrm{no}_{3}$ & Metanotum & HAO_0000603 \\
\hline not & Notaulus & HAO_0000647 \\
\hline ov & Ovipositor & HAO_0000679 \\
\hline $\mathrm{pl}_{1}$ & Propleuron & HAO_0000862 \\
\hline $\mathrm{pl}_{2}$ & Mesopleuron & HAO_0000566 \\
\hline pre & Prepectus & HAO_0000811 \\
\hline prp & Propodeum & HAO_0000051 \\
\hline ptl & Petiole & HAO_0000020 \\
\hline set & Seta & HAO_0002299 \\
\hline sctl & Mesoscutellum & HAO_0000574 \\
\hline tfs & Transfacial sulcus & HAO_0002016 \\
\hline $\operatorname{tg} \mid$ & Tegula & HAO_0000993 \\
\hline tps & Tentorial pit & HAO_0000999 \\
\hline
\end{tabular}




\section{Figure 1}

Digital microscopic images of Diversinitus attenboroughi holotype, male.

(A) Dorsal habitus. (B) Head frontal. (C) Antenna detail dorsal. (D) Head and mesosoma dorsal. (E) Wings left side. Scale bars: (A, C) $0.5 \mathrm{~mm}$, (B, E) $2.5 \mathrm{~mm}$, (D) $0.2 \mathrm{~mm}$. Abbreviations: $\mathrm{ax}=$ axilla, $\mathrm{F} 1 / 11=$ funicular $1 / 11$, frn $=$ frenum, $\mathrm{lbr}=$ labrum, $\mathrm{mps}=$ multiporous plate sensilla, $\mathrm{msc}=$ mesoscutum, $\mathrm{no}_{1}=$ pronotum, not $=$ notaulus, $\mathrm{sct}=$ scutellum, ptl = petiole. Photos by $\mathrm{M}$ Haas. 

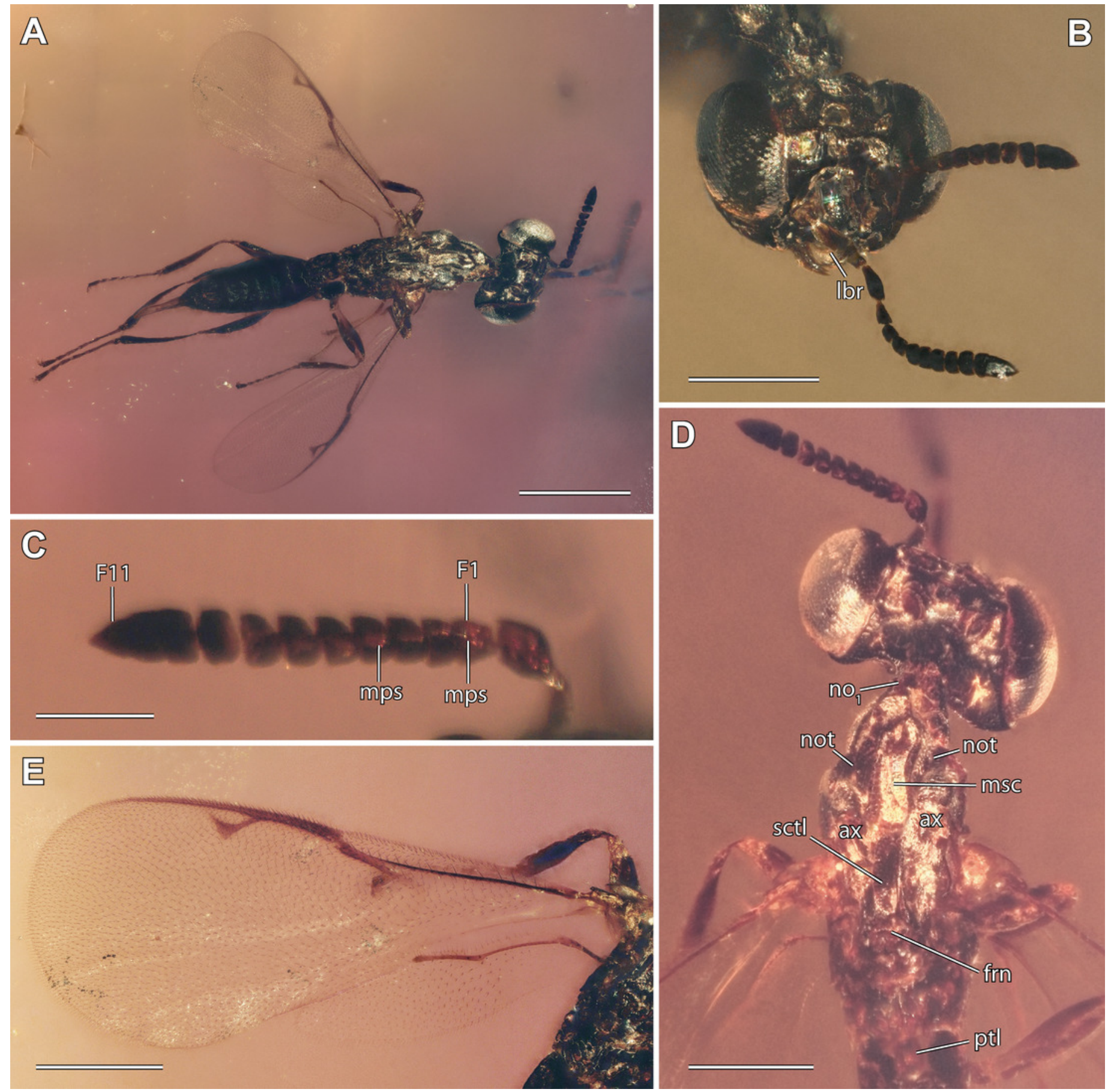
Figure 2

Digital microscopic images of Diversinitus attenboroughi lateral habitus, males.

(A) Holotype. (B) Paratype. Scale bars: $0.5 \mathrm{~mm}$. Photos by M Haas.

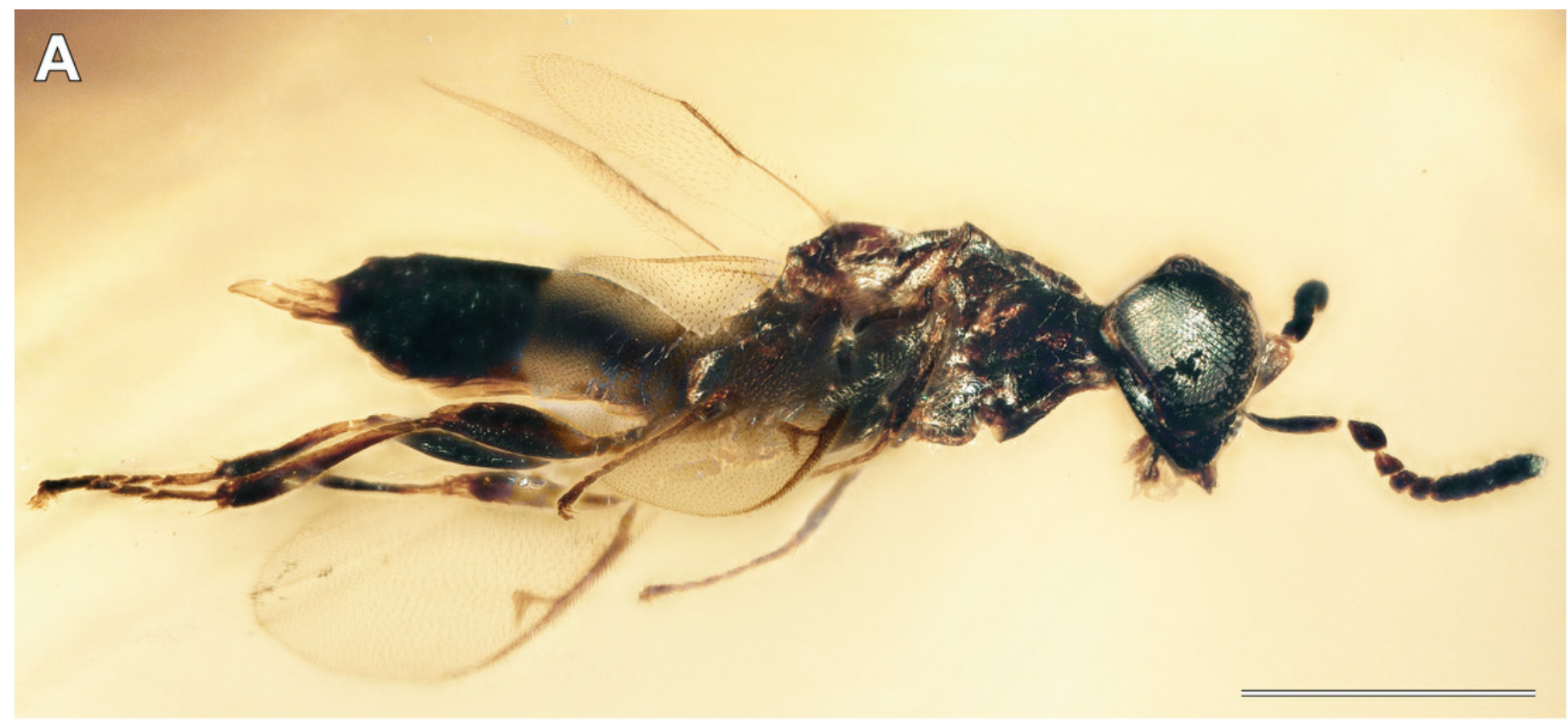

B

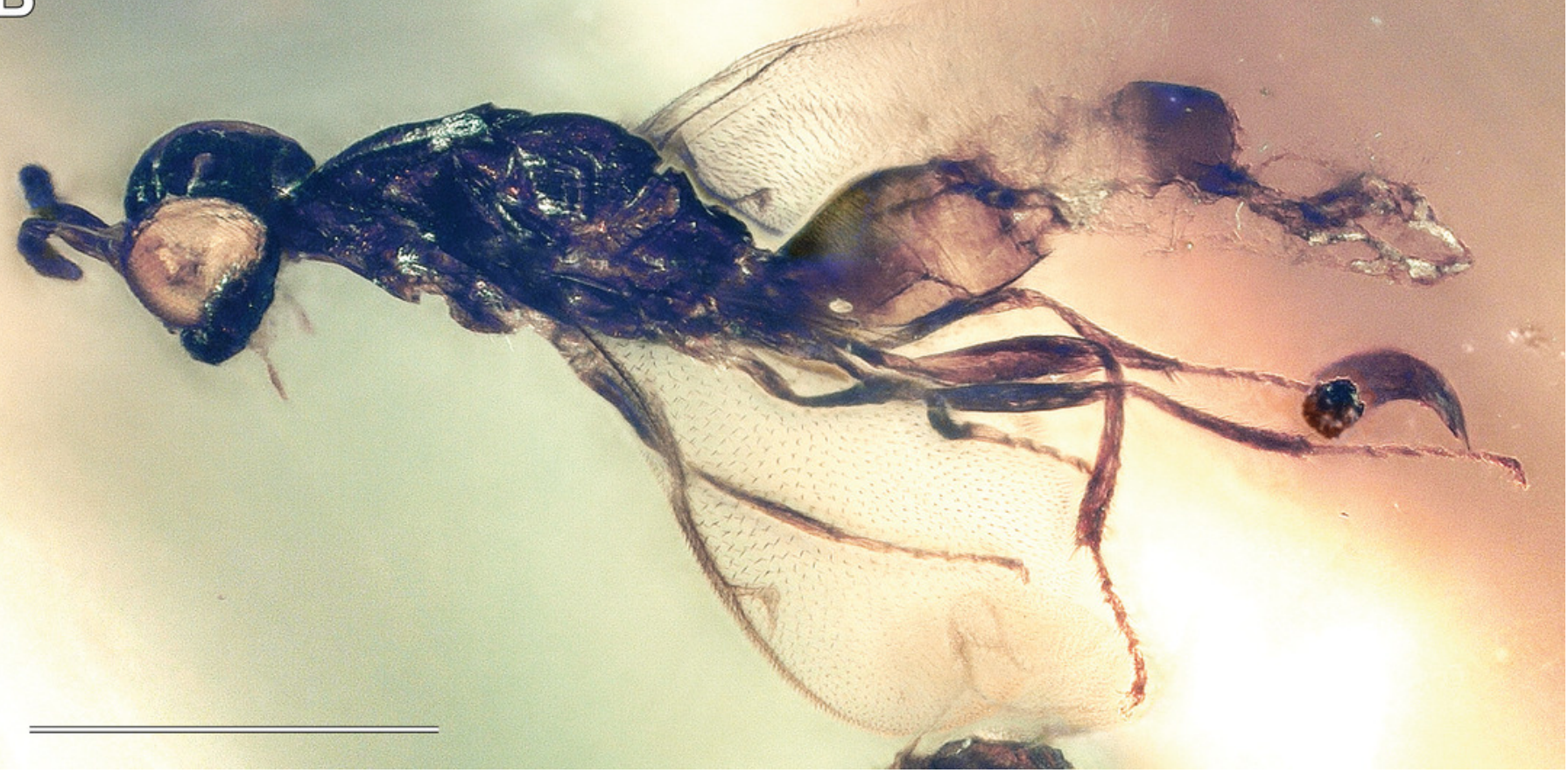




\section{Figure 3}

Habitus drawings of Diversinitus attenboroughi holotype, male.

(A) Habitus lateral. (B) Habitus dorsal. Scale bars: $0.5 \mathrm{~mm}$. Abbreviations: $a x=$ axilla, bv $=$ basal vein, cer $=$ cercus, $\mathrm{cx}_{1 / 2 / 3}=$ pro- $/$ meso- $/$ metacoxa, $\mathrm{F} 1 / 11=$ funicular $1 / 11$, frn $=$ frenum, $\mathrm{msc}=$ mesoscutum, $\mathrm{Mt}_{2}=$ metasomal tergum $2, \mathrm{Mt}_{8+9}=$ syntergum, $\mathrm{no}_{1}=$ pronotum, not $=$ notaulus, $\mathrm{pl}_{1}=$ propleuron, pre $=$ prepectus, $\mathrm{prp}=$ propodeum, $\mathrm{ptl}=$ petiole, $\mathrm{sct}=$ scutellum, $\operatorname{tgl}=$ tegula. Drawings by M Haas. 


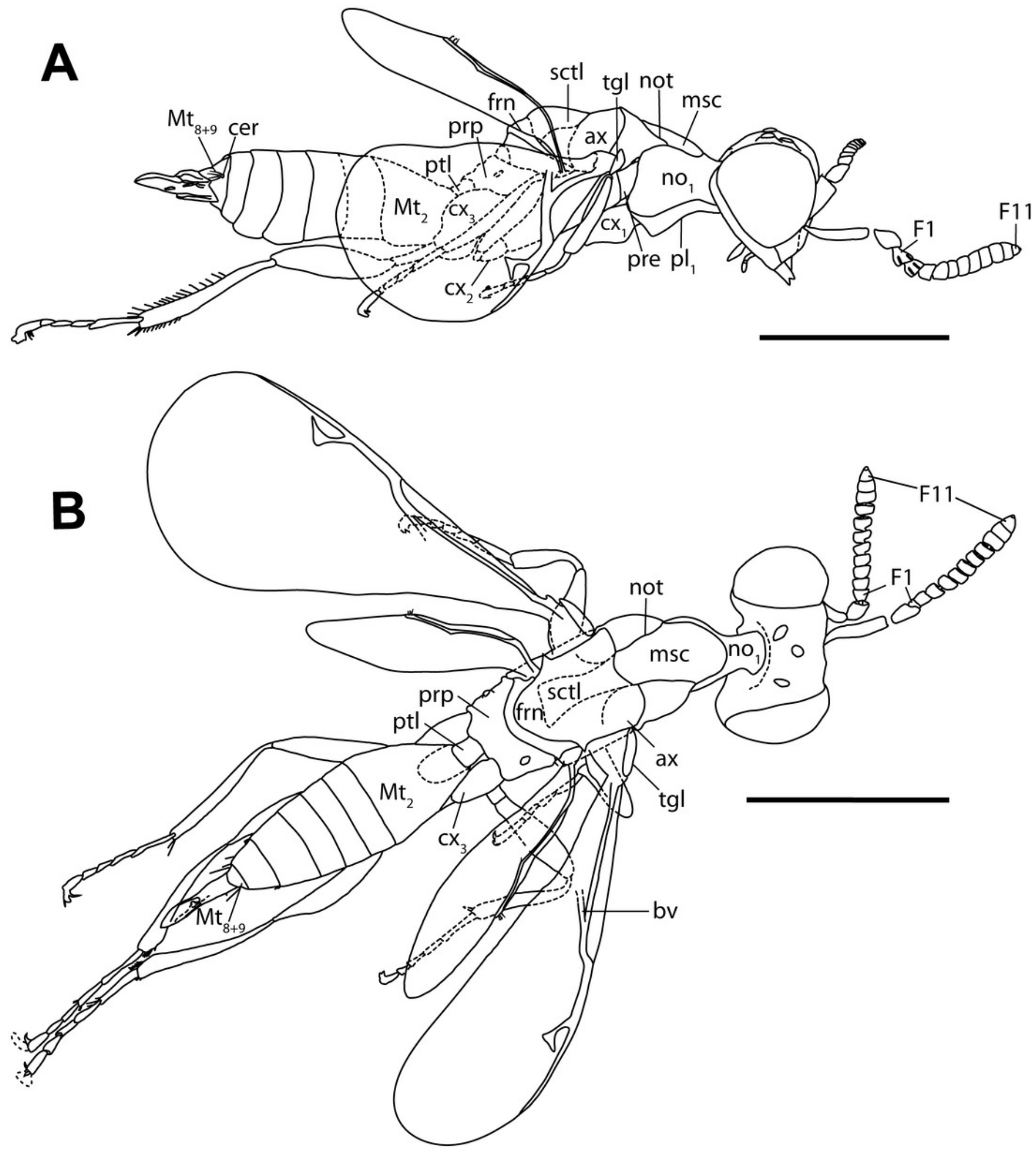




\section{Figure 4}

Digital microscopic images of Burminata caputaeria and Glabiala barbata, female.

(A, B, C) Burminata caputaeria (A) lateral habitus. (B) Head frontal. (C) Right antenna lateral.

(D, E, F, G) Glabiala barbata (D) lateral habitus. (E) Left antenna dorsal. (F) Mesosoma lateral.

(G) Mesosoma dorsal. Scale bars: (A, D) $0.5 \mathrm{~mm},(B, C, E, F, G) 0.1 \mathrm{~mm}$. Abbreviations: $a x=$ axilla, $\mathrm{F} 1 / 11=$ funicular $1 / 11$, frn $=$ frenum, $\mathrm{lbr}=$ labrum, $\mathrm{mps}=$ multiporous plate sensilla, $\mathrm{msc}=$ mesoscutum, $\mathrm{no}_{1}=$ pronotum, $\mathrm{no}_{3}=$ metanotum, $\mathrm{sct}=$ scutellum, $\mathrm{tfs}=$ transfacial sulcus, tps $=$ tentorial pits. Photos by $\mathrm{M}$ Haas. 

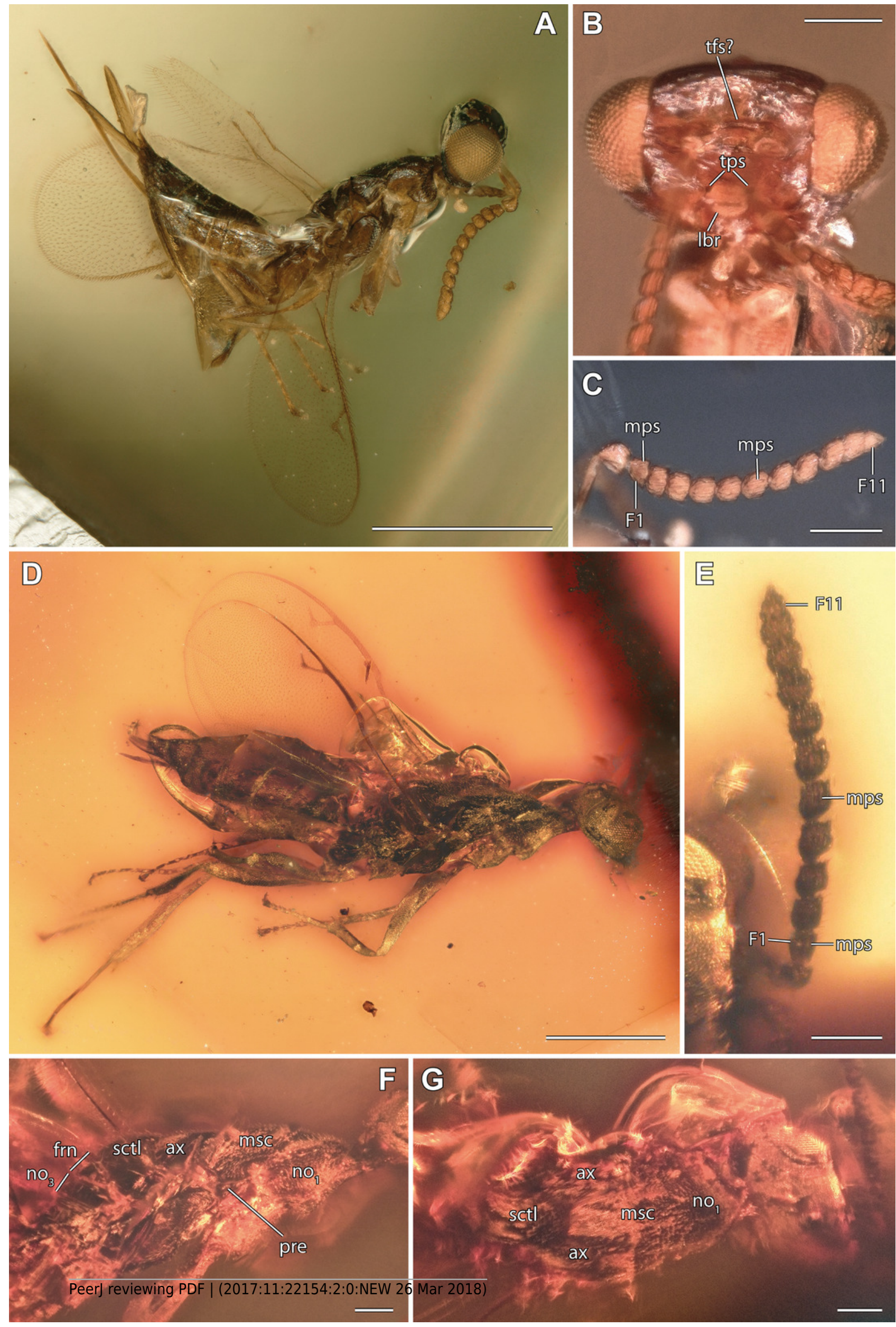


\section{Figure 5}

Habitus drawings of female holotypes of Burminata caputaeria (A) and Glabiala barbata (B).

Scale bars: $0.5 \mathrm{~mm}$. Abbreviations: $\mathrm{ax}=$ axilla, $\mathrm{bv}=$ basal vein, $\mathrm{cer}=$ cercus, $\mathrm{cx}_{1 / 2 / 3}=$ pro- $/$ meso- $/$ metacoxa, $\mathrm{F} 1 / 11=$ funicular $1 / 11, \mathrm{msc}=$ mesoscutum, $\mathrm{Mt}_{2}=$ metasomal tergum 2 , $\mathrm{Mt}_{8+9}=$ syntergum, $\mathrm{no}_{1}=$ pronotum, not $=$ notaulus, ov $=$ ovipositor, $\mathrm{pl}_{1 / 2}=$ pro- $/$ mesopleuron, pre $=$ prepectus, $\operatorname{prp}=$ propodeum, $\mathrm{sctl}=$ scutellum, $\mathrm{tgl}=$ tegula. Drawings by M Haas. 


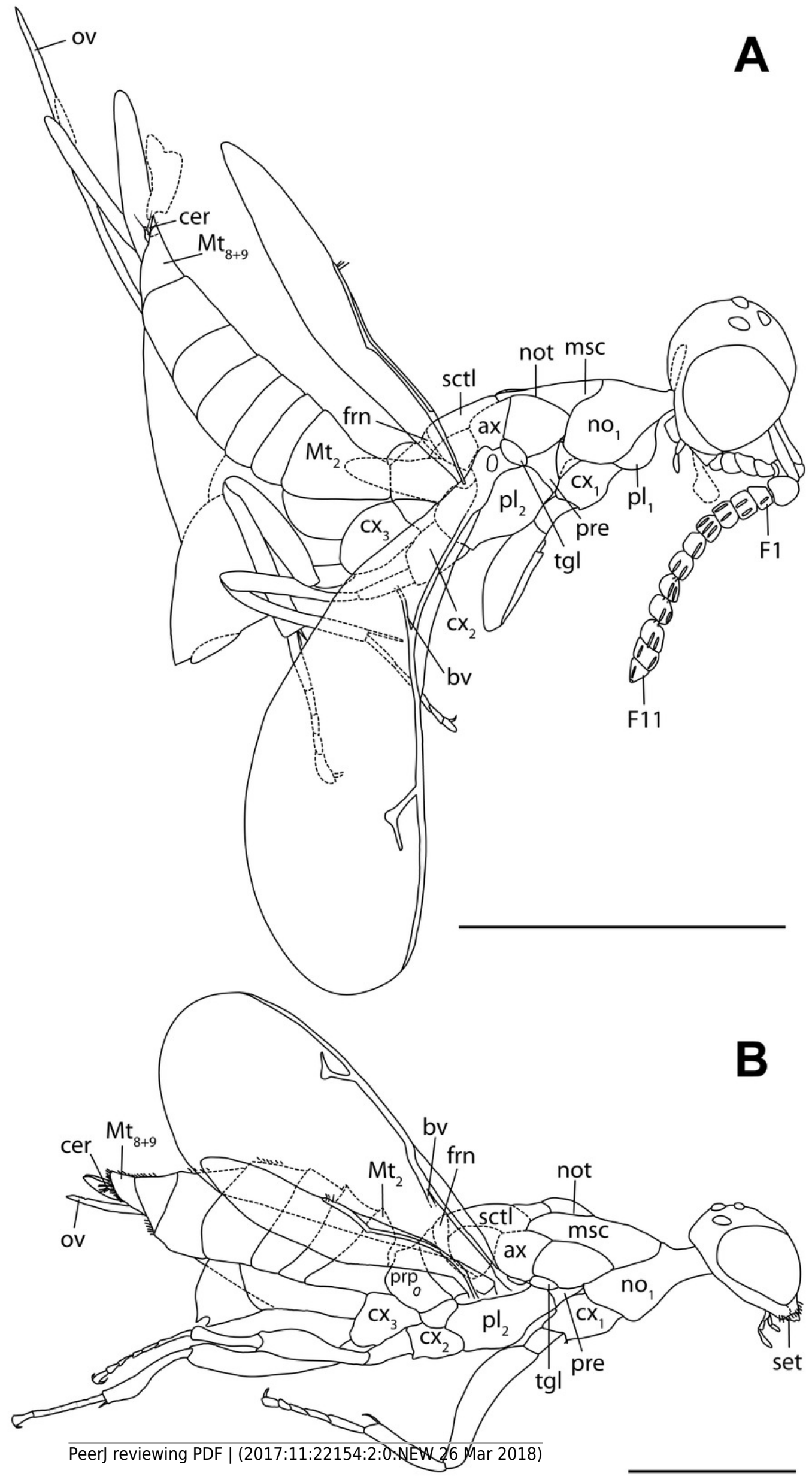




\section{Figure 6}

Phylogenetic placement of Diversinitidae within Chalcidoidea based on morphological characters.

Strict consensus tree calculated from 39 trees (tree length $=5861, \mathrm{Cl}=0.077, \mathrm{RI}=0.567$, 232 characters and 304 taxa, equal weights, new technology search). Yellow box highlights described fossils. Mymarommatoidea, potential sistergroup to all Chalcidoidea, collapsed and highlighted in blue. Green names indicate monophyletic and therefore collapsed families. Red names indicate monophyletic and therefore collapsed pteromalid subfamilies. Grey names indicate single taxa. For more information on the dataset of extant taxa refer to Heraty et al. (2013). 

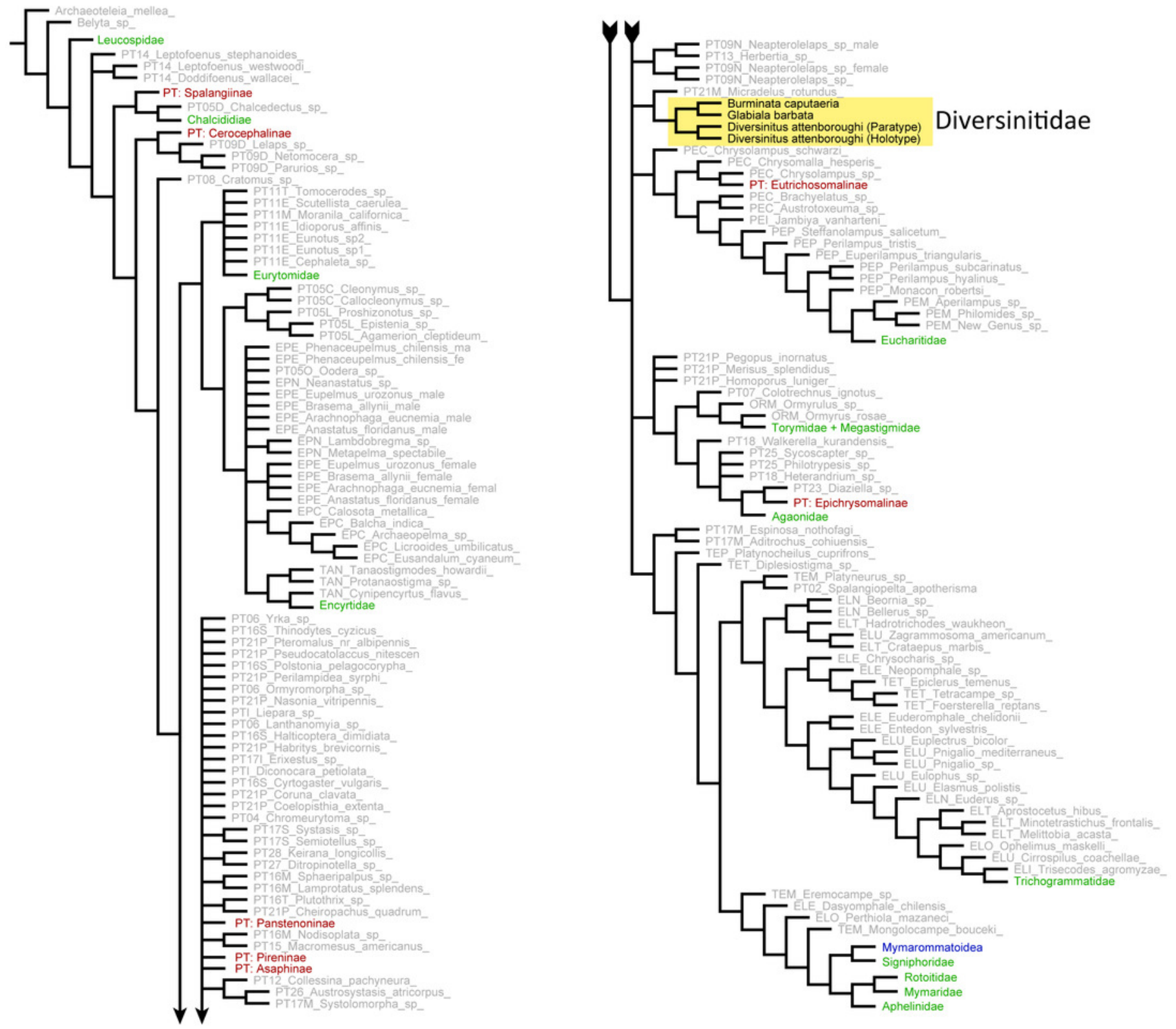